\title{
State of the Art for the Biosorption Process-a Review
}

\author{
Izabela Michalak • Katarzyna Chojnacka • \\ Anna Witek-Krowiak
}

Received: 7 January 2013 / Accepted: 26 April 2013 /

Published online: 12 May 2013

C The Author(s) 2013. This article is published with open access at Springerlink.com

\begin{abstract}
In recent years, biosorption process has become an economic and eco-friendly alternative treatment technology in the water and wastewater industry. In this light, a number of biosorbents were developed and are successfully employed for treating various pollutants including metals, dyes, phenols, fluoride, and pharmaceuticals in solutions (aqueous/oil). However, still there are few technical barriers in the biosorption process that impede its commercialization and thus to overcome these problems there has been a steadily growing interest in this research field. This resulted in large numbers of publications and patents each year. This review reports the state of the art in biosorption research. In this review, we provide a compendium of know-how in laboratory methodology, mathematical modeling of equilibrium and kinetics, identification of the biosorption mechanism. Various mathematical models of biosorption were discussed: the process in packed-bed column arrangement, as well as by suspended biomass. Particular attention was paid to patents in biosorption and pilot-scale systems. In addition, we provided future aspects in biosorption research.
\end{abstract}

Keywords Biosorption · Research methodology · Kinetics · Equilibrium · Process solutions · Application in practice

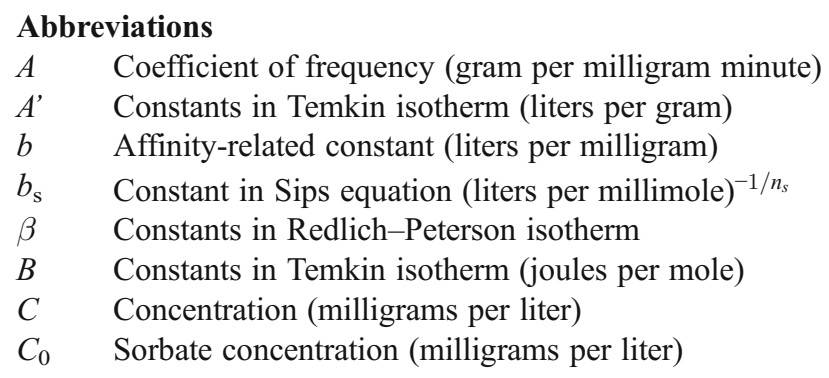

I. Michalak $(\bowtie) \cdot \mathrm{K}$. Chojnacka

Department of Chemistry, Institute of Inorganic Technology and Mineral Fertilizers, Wrocław University of Technology, Smoluchowskiego 25, 50-372 Wrocław, Poland e-mail: izabela.michalak@pwr.wroc.pl

A. Witek-Krowiak

Division of Chemical Engineering, Department of Chemistry, Wrocław University of Technology, Norwida 4/6, 50-373 Wrocław, Poland 
$C_{S} \quad$ Biosorbent content (grams per liter)

$D_{L} \quad$ Axial coefficient of diffusion (square centimeters per second)

$E_{\mathrm{a}} \quad$ Activation energy (joules per mole)

$\varepsilon \quad$ Bed porosity

$k \quad$ Process rate (grams per milligram minute)

$k_{\mathrm{F}} \quad$ Constants of Freudlich equation, (milligrams per gram)(liters per milligram) ${ }^{1 / \mathrm{nF}}$

$k_{\mathrm{RP}} \quad$ Constants in Redlich-Peterson isotherm (liters per gram)

$K_{0} \quad$ Equilibrium biosorption constant (liters per mole)

$\rho_{p} \quad$ Apparent density of sorbent (grams per milliliter)

$n_{\mathrm{F}} \quad$ Constants of Freudlich equation

$n_{s} \quad$ Exponent in Sips isotherm

$q \quad$ Sorption capacity (milligrams per gram)

$q_{\text {eq }} \quad$ Biosorption capacity of the biosorbent at equilibrium (milligrams per gram)

$q_{\max }$ The maximum biosorption capacity of the biosorbent (milligrams per gram)

$Q_{\mathrm{RP}} \quad$ Constants in Redlich-Peterson isotherm, (liters per milligram) ${ }^{\beta}$

$R \quad$ The universal gas constant, $8.314 \mathrm{~J} \mathrm{~mol} \mathrm{~K}^{-1}$

$t \quad$ Time (minute)

$T \quad$ Temperature (Kelvin)

$v \quad$ Linear velocity of flow (centimeters per minute)

$z \quad$ Axial coordinate of column (centimeters)

\section{Introduction}

The first paper on biosorption was published in 1951, since then, great efforts have been made to prepare efficient, effective, and economic biomaterials and their application for wastewater treatment. Due to the fascinating features of biosorption, it received huge expectations in academic, research, and industries. It was believed that by using this new method in which biomass is used as a sorbent, the toxic pollutants could be selectively removed from aqueous solutions to desired low levels. As the biomass exhibited a wide spectrum of desired properties, the biosorption concept has attracted paramount importance in various fields. Vital progress has been made to understand the complex biosorption mechanism, methods of its quantification (equilibrium and kinetics), being able to point out the factors that influence efficiency and the rate of the process over the past decades. Further, this process was tested to be implemented in pilot- and industrial-scale. The team of Professor Bohumil Volesky from McGill University, Canada and his company BV SORBEX made the greatest contribution to bring the laboratory biosorption process to an industrial scale. However, there appeared some problems that hindered the application of the biosorption process in an industrial scale. Although this process been discussed in the literature for 60 years with over 13,000 scientific papers in peer-reviewed journals, so far it has not been widely implemented in industrial practice.

The plausible reason that hindered the application of this process in the industrial scale was related to the low stability and low mechanical resistance of the biomass. Despite it exhibiting a very high ion exchange (biosorption) capacity, there appeared problems with the regeneration of the sorbent and its successive deterioration. The concept of recovery and reuse of a sorbent plays an essential role in success of the sorption process, in this perspective biosorption actually lost the competition with ion exchange. The recovery and reuse of biomass is essential, otherwise, it will be a difficult issue for sewage sludge management and a continuous supply of fresh sorbent-biomass will be required. 
Perhaps new concepts for the application of biosorption would enable practical use of the deep scientific knowledge discovered so far. The present work reports state-of-the-art and know-how in biosorption science and technology. A compendium of knowledge about the theory related to the process, research methodology, and applications is presented. This article is an essay on a specific direction in which research aimed at the process, with particular reference to dead ends, and an indication of the promising directions. Perhaps it will be a step forward towards the practical applications and the making use of biosorption in sustainable technologies of the future.

\section{Biosorption Research Progress}

Biosorption may be defined as the removal/binding of desired substances from aqueous solution by biological material. Such substances can be organic and inorganic and are either soluble or insoluble forms [1]. In the literature, sorptive properties of a wide range of natural biomasses are usually tested for wastewater treatment, especially where the concentration of pollutant is less than $100 \mathrm{mg} \mathrm{L}^{-1}$, and where the use of other treatment methods are ineffective and too costly [2].

\section{Biosorption: Definition}

Sorption is a term used for both absorption and adsorption, these terms are often confused. Absorption is the incorporation of a substance in one state into another different state (i.e., liquids being absorbed by a solid or gases being absorbed by water). Adsorption is the physical adherence or bonding of ions and molecules onto the surface of the solid material. In this case, the material accumulated at the interface is the adsorbate and the solid surface is the adsorbent [1]. Biosorption is a subcategory of adsorption, where the sorbent is a biological matrix.

Biosorption is a process of rapid and reversible binding of ions from aqueous solutions onto functional groups that are present on the surface of biomass. This process is independent on cellular metabolism [3]. Biosorption is presented in the literature as efficient and selective process. Biosorption can be performed in a wide range of $\mathrm{pH}$ values 3-9 and temperature values $4-90{ }^{\circ} \mathrm{C}$. As the optimum biosorbent particle size is between 1 and 2 $\mathrm{mm}$, the equilibrium state of both adsorption and desorption is achieved very quickly. This process does not require a high capital investment thus the operating costs are economical. In addition, the biological materials are often inexpensive and can be obtained from agriculture or from industrial waste [4]. The fascinating features of biosorption over conventional treatment methods include: low cost, high efficiency, minimization of chemical and or biological sludge, no additional nutrient requirement, regeneration of biosorbent, and possibility of metal recovery [5].

\section{Biosorbents}

A wide range of biomaterials available in nature has been employed as biosorbent for the desired pollutant removal. All kinds of microbial, plant and animal biomass and their derivative products, have received great interest in a variety of ways and in relation to a variety of substances [6-8]. However, in recent years attention has been driven towards the agricultural waste materials, polysaccharides, and industrial waste biomaterials [9-12]. Among these biomaterials, chitosan a natural amino polysaccharide has received wide attention to treat a large number of aquatic pollutants due its high contents of amino and hydroxyl functional groups. 
Further, a vast array of biological materials, especially bacteria, cyanobacteria, algae (including microalgae, macroalgae, seaweeds), yeasts, fungi, and lichens have drawn much attention for removal and recovery of heavy metal ions due to their good performance, low cost, and availability in large quantities. Due to the presence of abundant chelating functional groups, all biological materials, have greater affinity for metal ions [13].

Apart from the above-mentioned natural biosorbents, in the literature, few other biomaterials have received much interest and they are: rice husk [14], coconut shell [15], plant barks [16, 17], leaves [18, 19], sawdust [20, 21], sugarcane bagasse [22], and peat moss [23]. From the above discussed biomaterials, special attention was given to the application of fly ash which was generated during burning of coal as a useful sorbent [24-26]. Fly ash is a strong alkaline material with negatively charged surface at higher $\mathrm{pH}$. Hence, it can be expected that metal ions can be removed from aqueous solutions by precipitation, electrostatic attraction [25], and ion exchange [26]. In an investigation of Chojnacka and Michalak (2009), it was also reported that the utilization of ashes from biological origin (wood and bone ash) will be a promising alternative to conventional adsorbents used for wastewater treatment [27]. A general scheme of different kinds of biosorbents used in biosorption process is presented in Fig. 1.

In general, biosorbents are usually prepared from the naturally abundant waste biomass by inactivation and are usually pretreated by washing with acid or base before the final drying [6]. Some types of biomass have to be either immobilized by a synthetic polymer matrix [28] or grafted onto an inorganic support material such as silica in order to achieve particles with the required mechanical properties [29]. Furthermore, simple cutting or grinding of dry biomass provides stable biosorbent particles with desired size [30].

In general, most of the biosorbent used were of dead biomass; this exhibits specific advantages in comparison with the use of living microorganisms: dead cells can be easily stored or used for longer time periods, dead biomass is not the subject to metal toxicity limitations, nutrient supply does not required, metal ion-loaded biosorbents can be easily desorbed and reused [31, 32]. However, the use of non-living biomass in powdered form has some disadvantages such as: difficulty in separation of biomass from the reaction system, mass loss after regeneration, poor mechanical strength, and small particle size which makes it difficult to use in batch and continuous systems [33]. However, these problems can be overcome by using a suitable immobilization method.

\section{Sorbates}

A wide range of target sorbates have been removed from aqueous solutions using biosorbents including metals, dyes, fluoride, phthalates, pharmaceuticals, etc. Nevertheless, most biosorption research focused on removal of metal ions and related elements, including actinides, lanthanides, metalloids, and various radioisotope ions of these substances. Additionally, particulates and colloids have been studied as well as organometal(loid) and organic compounds, including dyes [7, 34].

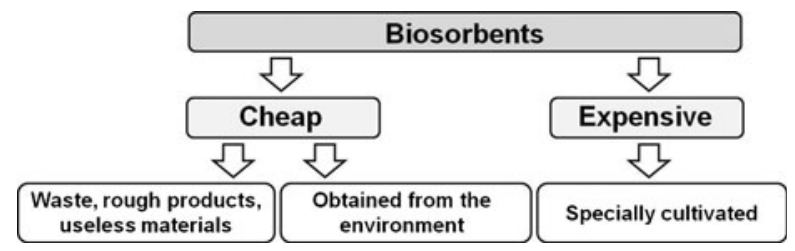

Fig. 1 General sourcing scheme for different kinds of biosorbents used in biosorption process 


\section{Biosorption of Cations/Anions}

In the literature, majority of the experiments were concerned with the biosorption of metal cations. While a large portion of current research has been carried on the removal of heavy metal cations (i.e., $\mathrm{Pb}(\mathrm{II}), \mathrm{Cd}(\mathrm{II}), \mathrm{Zn}(\mathrm{II}), \mathrm{Cu}(\mathrm{II})$, etc.), the importance of anions removal using biosorption has become a growing concern in the fields of mining, metallurgical, and surface finishing industries. A number of toxic metals and metalloids, such as arsenic, selenium, chromium, molybdenum, and vanadium which occur in industrial wastewater effluents in anionic form, should be taken into account. In general, most of these anionic species are conventionally removed by using activated carbon process, ion exchange, solvent extraction, precipitation [35]. However, in recent years, biosorption has been successfully employed for the effective treatment of anionic pollutants from wastewater. Whereas biosorption of anionic species has not been studied as widely as cationic biosorpiton. Kratochvil (1997) had proposed a mechanism of chromate biosorption by brown macroalga Sargassum, whereby anionic chromate was bound through acid sorption: biomass $+\mathrm{H}^{+}+\mathrm{HCrO}_{4}{ }^{-}=$biomass $-\mathrm{H}_{2} \mathrm{CrO}_{4}$, some of the chromate were reduced by Sargassum to $\mathrm{Cr}(\mathrm{Ill})$ that was then bound to the acidic groups on Sargassum [36].

Giles et al. (1958a, b) described dye sorption to $-\mathrm{SO}_{3}{ }^{-}$of chitin. The following reaction was proposed: chitin $-\mathrm{NH}+\mathrm{H}^{+}+$dye $-\mathrm{SO}_{3}{ }^{-}=$chitin $-\mathrm{NH}_{2}{ }^{+}-\mathrm{SO}_{3}-$ dye. The authors attributed the dye sorption by chitin amide to the electrostatic attraction. Therefore, only when the solution $\mathrm{pH}$ is lower than the corresponding $\mathrm{p} K_{a}$ (acidic constant), the amine/amide sites could be effectively protonated with a positive charge, and an anion could thus be bound [37, 38].

Biosorption of molybdate $\left(\mathrm{MoO}_{4}{ }^{2-}\right)$ by chitosan or chitin has been studied recently [39, 40]. In order to avoid the dissolution of biosorbent beads under acidic conditions, chitosan was partially cross-linked with glutaraldehyde. Dambies et al. (1999) studied the arsenic sorption on molybdate-impregnated chitosan gel beads. It was found that the sorption capacity of raw chitosan for $\mathrm{As}(\mathrm{V})$ was increased by impregnation with molybdate. While the extraction of chitin or chitosan is cost effective process, natural biomaterials containing them do have a potential for anion biosorption [41].

\section{Mechanism: Biosorbent-Sorbate Interactions}

The binding mechanism of sorbate onto biosorbent in biosorption mechanism is a complex process. The binding of metal ions by natural materials may occur through biosorptionphysical (electrostatic interaction and van der Waals forces) or chemical-displacing of either bound metal cation (ion exchange) or a proton (proton displacement), complexation, chelation (ionic and covalent interaction) [3, 6, 42]. The factors that influence the biosorption process can be distinguished as: physical and chemical properties of metal ions (i.e., molecular weight, ionic radius, oxidation state), properties of biosorbent (i.e., the structure of the biomass surface), and the process parameters (i.e., $\mathrm{pH}$, temperature, concentration of biosorbent, the concentration of sorbate). $\mathrm{pH}$ is one of the key factors that influences not only dissociation of sites, solution chemistry of metal ions, hydrolysis, complexation by organic and/or inorganic ligands, redox reactions, precipitation, but also strongly influences the speciation and the biosorption affinity of metal ions [43-45]. The analysis of the influence of parameters on the biosorption properties of sorbents is a prerequisite to understand the mechanism of biosorption which is complex and has not been thermodynamically explained yet.

The composition of the cell wall is of great importance to the biosorption process. The cell wall of biomasses is composed mainly of polysaccharides, proteins and lipids, and 
contains a number of functional groups: hydroxyl, carboxyl, amino, ester, sulfhydryl, carbonyl-terminal end, carbonyl-internal which play a key role in the biosorption of cations from aqueous solutions [46]. Depending on $\mathrm{pH}$, different functional groups participate in metal ion binding: $\mathrm{pH}$ 2-5: carboxyl, $\mathrm{pH}$ 5-9: carboxyl and phosphate, $\mathrm{pH}$ 9-12: carboxyl, phosphate and hydroxyl (or amine) [47]. During the biosorption process, protons and/or light metal cations $\left(\mathrm{Na}^{+}, \mathrm{K}^{+}, \mathrm{Mg}^{2+}, \mathrm{Ca}^{2+}\right)$ which are naturally bound with functional groups located on the surface of biomass (i.e., macroalgae), are exchanged with metal cations present in aqueous solution [3]. As an example, the exchange of divalent metal ions with monovalent $\mathrm{Na}^{+}$ions bound with a phosphoryl group is presented below (1) [48]:<smiles>[R]COP(=O)([O-])[O-]</smiles>

\section{Techniques Used in the Identification of Biosorption Mechanism}

A number of analytical techniques have been employed for the elucidation of biosorption mechanism (Fig. 2).

- Titration

The functional groups on a material surface that has acidic or basic properties and ionexchange properties can be easily determined by titration methods. The surface groups present on biosorbents can be identified by the Boehm method or potentiometric titration. In the Boehm method, the acidic sites are determined by mixing small quantities $(0.1 \mathrm{~g})$ of biosorbent with $10 \mathrm{~mL}$ of different bases $\left(0.1 \mathrm{M} \mathrm{NaOH}, 0.1 \mathrm{M} \mathrm{NaHCO}_{3}\right.$, or $0.05 \mathrm{M}$ $\mathrm{Na}_{2} \mathrm{CO}_{3}$ ) in $25-\mathrm{mL}$ beakers. Furthermore, these beakers are sealed and shaken for $24 \mathrm{~h}$. The solutions are then filtered and titrated with $0.05 \mathrm{M} \mathrm{H}_{2} \mathrm{SO}_{4}$. Similarly, the basic sites are determined by mixing $0.1 \mathrm{~g}$ of biosorbent with $10 \mathrm{~mL}$ of $0.1 \mathrm{M} \mathrm{HCl}$. The obtained solutions

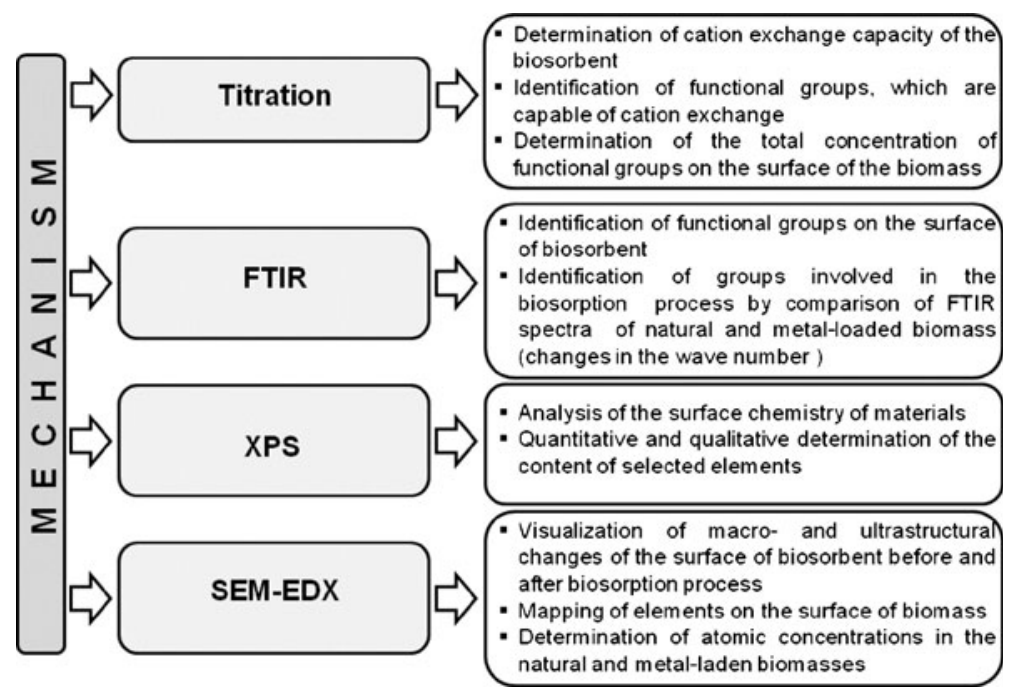

Fig. 2 Techniques used in the identification of mechanism of biosorption 
are titrated with $0.1 \mathrm{M} \mathrm{NaOH}$ [49]. By potentiometric titration, the functional groups which are present on the cell wall structure and their total concentration in the biomass can be determined as reported elsewhere [50]. Experimental procedure is as follows: deionized water (blank sample) and $0.2 \mathrm{~g}$ of the biomass suspended in deionized water $(200 \mathrm{~mL})$ should be titrated with $0.1 \mathrm{M} \mathrm{NaOH}$ till $\mathrm{pH} 11.5$ and reversely with $0.1 \mathrm{M} \mathrm{HCl}$ to $\mathrm{pH} 2.5$. The $\mathrm{pH}$ of the biomass suspension should be recorded after each addition of titrant, after stabilization of the record. Before experiment, water should be bubbled with argon for $3 \mathrm{~h}$ in order to purge it of dissolved $\mathrm{CO}_{2}$. Experimental data from the potentiometric titration of biosorbent should be fitted to models which consider the presence of one, two, or three types of functional groups present on the biomass surface [50].

Biosorbents possess functional groups with distinguishable $\mathrm{p} K_{\mathrm{a}}$, i.e., for the weak acidic carboxyl groups $\mathrm{R}-\mathrm{COO}^{-}$(apparent $\mathrm{p} K_{\mathrm{a}}$ in the range 3.5-5.0) and for sulfonic acid $\mathrm{R}-\mathrm{SO}_{4}{ }^{-}$ (apparent $\mathrm{p} K_{\mathrm{a}}$ in the range 1.0-2.5) [51]. Protonated amino groups have a $\mathrm{p} K_{\mathrm{a}}$ value of ca. 8 [52]. Potentiometric titration of the biomass can be performed to evaluate cation exchange capacity of the biosorbent - replacement of an ion in a solid phase in contact with a solution by another ion [1]. Cation exchange capacity of macroalga can be determined from the titration curve as the quantity of titrant (either acid or base) used per unit mass of the biosorbent in $\mathrm{pH}$ range $2.5-11.5$ and in the presence of all functional groups [34, 53].

- Fourier Transform Infrared Spectroscopy

To explore the biosorption mechanisms, it is essential to identify the sorbent functional groups that are involved in the biosorption process. FTIR spectroscopy offers important information related to the nature of the bonds and allows identification of different functional groups on the cell wall structure. The extent of band shifting in natural and metal-loaded biomass gives an indication of the degree of interaction of functional groups with metal cations [54]. Below presented are exemplary stretching frequencies observed in FTIR spectra of biomaterials: wavenumber 3,280 $\mathrm{cm}^{-1}$ : bonded $-\mathrm{OH},-\mathrm{NH}$ stretching $[51] ; 2,920 \mathrm{~cm}^{-1}$ : asymmetric stretch of aliphatic chains $(-\mathrm{CH})$ [55]; $2,854 \mathrm{~cm}^{-1}$ : symmetric stretch of aliphatic chains $(-\mathrm{CH})[55] ; 1,740 \mathrm{~cm}^{-1}: \mathrm{C}=\mathrm{O}$ stretch of $\mathrm{COOH} ; 1,630 \mathrm{~cm}^{-1}$ : asymetric $\mathrm{C}=\mathrm{O}[56] ; 1,530 \mathrm{~cm}^{-1}$ : amide II [51]; $1,450 \mathrm{~cm}^{-1}$ : symmetric $\mathrm{C}=\mathrm{O}$ [56]; $1,371 \mathrm{~cm}^{-1}$ : asymmetric $-\mathrm{SO}_{3}$ stretching [57]; $1,237 \mathrm{~cm}^{-1}$ : C-O stretch of $\mathrm{COOH}[56] ; 1,160 \mathrm{~cm}^{-1}$ : symmetric $-\mathrm{SO}_{3}$ stretching [57]; $1,117 \mathrm{~cm}^{-1}$ : C-O (ether); 1,033 $\mathrm{cm}^{-1}: \mathrm{C}-\mathrm{O}$ (alcohol) [51], $817 \mathrm{~cm}^{-1}: \mathrm{S}=\mathrm{O}$ stretch [57].

- Scanning Electron Microscopy with an Energy Dispersive X-ray Analytical System

Scanning electron microscopy (SEM) is a powerful technique which can be used to investigate surface morphology of biosorbent before and after metal ion biosorption [58]. In particular, this technique allows in evaluating morphological changes of the biomass surface (for example changes in the cell wall structure after metal ions binding. In addition, when SEM is combined with EDX technique, it provides valuable information regarding the distribution of various elements on the biomass surface [57]. It should be emphasized that SEM provides only a qualitative evaluation of the surface structure. As an example, SEM images of alga Ulva prolifera before and after biosorption of $\mathrm{Cr}$ (III) ions present the morphological changes of biomass surface (Fig. 3).

- X-ray Photoelectron Spectroscopy Analysis

X-ray photoelectron spectroscopy analysis (XPS) also known as electron spectroscopy for chemical analysis is a quantitative spectroscopic technique which allows analyzing the surface chemistry of materials. This technique provides valuable information about elemental composition, empirical formula, and the electronic state of the element present in a material. This technique was often used in biosorption studies to obtain the information about biosorption mechanism, oxidation state of sorbed element on the surface of the 

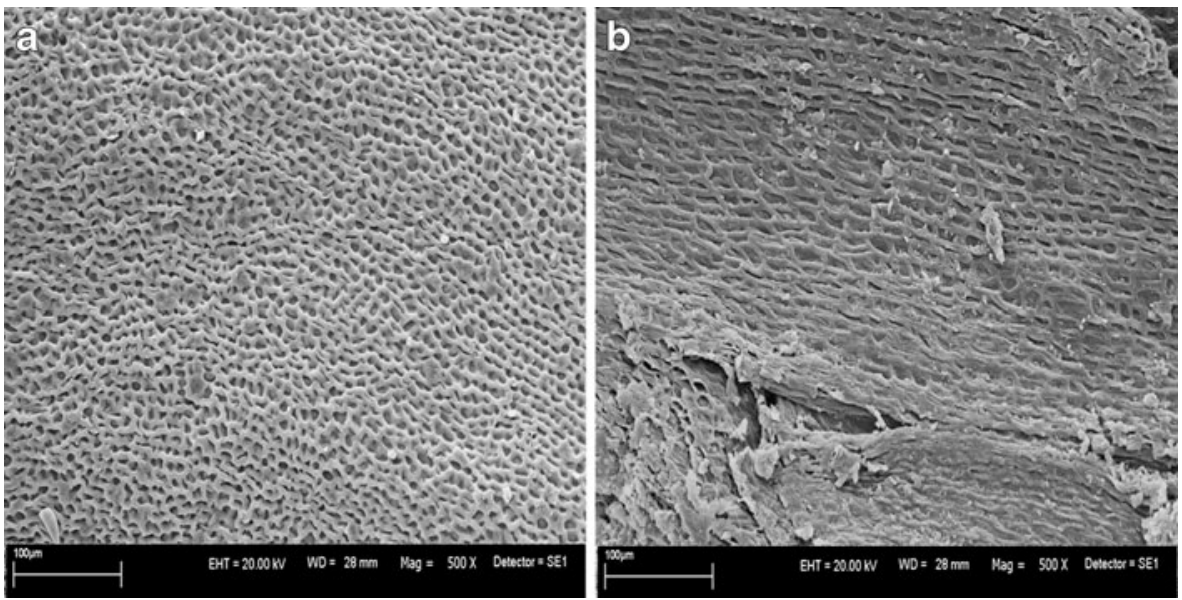

Fig. 3 SEM images of natural and enriched with Cr(III) biomass of Ulva prolifera (SEM, Leo Zeiss 435) [59]

biomaterials [60-62]. For example, in an investigation, XPS was used to obtain the information of change in oxidation state of the Cr bound to the biological material (Ecklonia sp.), and it was observed that biosorption mechanism involves reduction $\mathrm{Cr}(\mathrm{VI})$ into $\mathrm{Cr}(\mathrm{III})$ [61]. In another study, adsorption-coupled reduction process was found during removal of $\mathrm{Cr}(\mathrm{VI})$ from water using buckwheat hull using XPS analysis [62].

\section{Biosorption in Single and Multi-metal Systems}

Biosorption of various metal ions by different kinds of biomaterials has been well reported in the literature. The majority of the published work demonstrates single-metal biosorption systems. However, most of the industrial effluents contain multi-metal ions thus it is essential to evaluate the performance of biosorbents in multi-metal aqueous solutions. Very little information is available on multi-metal biosorption in binary [63-68], ternary [64-69], and quaternary systems [70]. These types of systems are investigated by using different methodologies so it is difficult to draw meaningful and universal conclusions. Indeed, multimetal systems need to be experimentally examined because they better reflect real effluents from industrial operations. In addition, another issue which is often neglected in the reported literature was investigation of the effects of anions on biosorption processes. This aspect should also be taken into consideration because the presence of anions in aqueous solutions could affect biosorption of metal cations [71].

In the available literature, two aspects related to the effects of anions on biosorption processes are considered: effects of anions on the maximum biosorption capacity of singlemetal systems [72] and the effects of anion concentration on the biosorption of various metal ions in multi-metal systems [71-74]. It is also important to emphasize that the influence of the anion on the biosorption capacity could differ depending on the nature of the biosorbent. In an investigation related to the fungus Aspergillus niger for biosorption of $\mathrm{Cr}(\mathrm{VI}), \mathrm{Co}(\mathrm{II})$, $\mathrm{Ni}(\mathrm{II})$, and $\mathrm{Zn}(\mathrm{II})$ ions, it was found that the effect of anions $\mathrm{NO}_{3}{ }^{-}$and $\mathrm{SO}_{4}{ }^{2-}$ did not significantly influence the removal efficiently, whereas the presence of $\mathrm{Cl}^{-}$anions significantly lowered the efficiency of metal ions biosorption in multi-metal systems [73]. In another study on the fungus Rhizopus arrhizus, it was observed that the degree of inhibition of the biosorption of $\mathrm{La}(\mathrm{III}), \mathrm{Cd}(\mathrm{II}), \mathrm{Pb}$ (II), and $\mathrm{Ag}(\mathrm{I})$ cations generally followed the order 
EDTA $>\mathrm{SO}_{4}{ }^{2-}>\mathrm{Cl}^{-}>\mathrm{PO}_{4}{ }^{3-}>$ glutamate $>\mathrm{CO}_{3}{ }^{2-}$ [75]. During biosorption of $\mathrm{Co}$ (II) cations by the brown macroalga Ascophylum nodosum, the presence of $\mathrm{SO}_{4}{ }^{2-}$ and $\mathrm{PO}_{4}{ }^{3-}$ anions did not result any change in biosorption, in contrast to $\mathrm{NO}_{3}{ }^{-}$anions which were the strongest inhibitor [76]. The opposite situation was observed in the case of $\mathrm{Zn}$ (II) biosorption by the cyanobacterium Oscillatoria anguistissim, in which the inhibitory order of the anions was as follows: $\mathrm{SO}_{4}{ }^{2-}>\mathrm{Cl}^{-}>\mathrm{NO}_{3}{ }^{-}$(i.e., $\mathrm{SO}_{4}{ }^{2-}$ anions were the strongest inhibitor) [74]. As mentioned earlier, the influence of the anion on biosorption capacity will differ depending on the metal ion oxidation state. For example, Han et al. (2008) observed the following inhibitory orders for the biosorption of $\mathrm{Cr}(\mathrm{VI})$ and $\mathrm{Cr}(\mathrm{III})$ ions, respectively: $\mathrm{NO}_{3}{ }^{-}>\mathrm{Cl}^{-}>\mathrm{SO}_{4}{ }^{2-}$ and $\mathrm{SO}_{4}{ }^{2-}>\mathrm{Cl}^{-} \approx \mathrm{NO}_{3}{ }^{-}[71]$.

\section{Kinetics and Equilibrium Modelling}

\section{Biosorption Kinetics}

Biosorption kinetics demonstrates the rate of solutes bonding on the surface of the biological materials. The description of the kinetics of biosorption is complex due to the many facets of the process. Kinetics studies provide the important information about the possible mechanism of biosorption that involves the diffusion (bulk, external, and intraparticle) and chemical reactions. In general, it is assumed that sorbate transport occurs in the few following steps. The first step involves the external diffusion (the substrates diffuse from the bulk solution to the external surface of the sorbent), the second step was due to the transport of the solute across the boundary layer, and the third step involves transfer of compounds in the pores to the internal parts of the sorbent and finally uptake of molecules by the active sites, and the fourth step involves sorption and desorption of sorbate. Numbers of mathematical models were available in the literature to evaluate the kinetics studies. This mathematical modelling of biosorption kinetics provides information about controlling the step of the process and possible mechanism of binding selected compounds [77]. Kinetic models can be chosen depends on the nature of biosorbent, type of solutes, and experimental conditions of the process.

Among the various kinetic models that are available in the reported literature, the models based on the order of chemical reaction are of particular interest (Table 1), especially the Lagergren (pseudo-I-order, PFO) (Eq. 2) and Ho (pseudo-II-order, PSO) models (Eq. 3). These models are based on the assumption that the rate of sorption is proportional to the number of free sites on the surface of the sorbent in the proper power (first or second). In a recent study, pseudo-first-order and pseudo-second-order equations were used to fit the experimental data of $\mathrm{Cu}(\mathrm{II})$ and $\mathrm{Cr}(\mathrm{VI})$ removal by soybean meal waste [9]. It was found that the results were better fitted to the pseudo-second-order model with high correlation coefficient $\left(R^{2}>0.99\right)$. Baysal et al. [31] investigated the kinetics of biosorption of $\mathrm{Pb}(\mathrm{II})$ onto Candida albicans biomass by varying the initial concentrations. The results showed the biosorption was best fitted to the pseudo-second-order model at all the studied concentration ranges. In comparison with both pseudo-first-order and pseudo-second-order models, it was observed in the literature that most of the biosorption process follows the pseudo-second-order model [10, 11, 16-21]. Biosorption is, however, a complex process, where the multitude of mechanisms does not allow to obtain sufficient knowledge about the order of reaction. The order of the reaction can be calculated on the basis of a generalized order equation (Eq. 4) without having prior assumption of the order of reaction (Liu and Shen model [80]).

Dynamics of the biosorption process were further evaluated by using various diffusive models (Table 2). These models are based on the assumption that the step that limit the rate 
Table 1 Kinetic models based on the order of chemical reaction

\begin{tabular}{llll}
\hline Model & Differential equation & Nonlinear equation & Ref. \\
\hline PFO & $(2) \frac{d q_{t}}{d t}=k_{1}\left(q_{e}-q_{t}\right)$ & $q_{t}=q_{e}\left(1-e^{-k_{1} t}\right)$ & {$[78]$} \\
PSO & $(3) \frac{d q_{t}}{d t}=k_{2}\left(q_{e}-q_{t}\right)^{2}$ & $q_{t}=q_{e} \frac{q_{e} k_{2} t}{1+q_{e} k_{2} t}$ & {$[79]$} \\
GO & $(4) \frac{d q_{t}}{d t}=k_{n}\left(q_{e}-q_{t}\right)^{n}$ & $q_{t}=q_{e}-\left[q_{e}^{1-n}-(1-n) k_{n} t\right]^{\frac{1}{(1-n)}}$ & {$[80]$} \\
\hline
\end{tabular}

of biosorption are related with diffusion of molecules: (a) transfer (diffusion) of the sorbate molecules to the border film of the sorbent, (b) diffusion of the molecules into the inside of the pores of the sorbent, (c) binding of the molecules of the sorbate to the active sites of the sorbent. The Weber-Morris intraparticle diffusion model has been widely used to describe these three phases $[11,20]$. Although malachite green biosorption onto beech sawdust [21] followed second order kinetics, it was shown that intra-particle diffusion might also play some role. Authors reported that the Weber-Morris model describes well the kinetics of biosorption for the first 10 min of the process. The Chrastil diffusive model (Eq. 6) is used for the calculation of the kinetics of the systems limited by diffusion. The Reichenberg model (Eq. 7) allows for calculating the phase that limits diffusion that takes place in the boundary film and in the pores of the sorbent.

\section{Equilibrium Modelling}

Equilibrium processes of biosorption are usually carried out in batch reactors, in laboratories, we are using conical flasks with agitation. The sorption process at the boundary between solid and liquid phase is a more complex process than the adsorption of gases. The extent of biosorption depends on the interaction between the biosorbent and each of the constituents of the solution. A number of mathematical models (linear and nonlinear) are available in the reference literature that describe the isotherms of biosorption. The most widely used mathematical models to describe sorption isotherms are presented in Table 3.

Volesky (2003) reported that sorbents can be compared on the basis of the course of the sorption isotherms [7]. It is essential that the mentioned comparison can be based on the trace of the isotherms for both low and high equilibrium concentrations of the sorbate in the solution. Comparing two sorbents in low equilibrium concentration of solute may give different uptake values than in high solute concentration. It is important to choose proper concentration range to compare possible materials and their capacities.

- Modelling in the Column Arrangement

Along with batch, equilibrium studies were further evaluated in column reactors.

Various mathematical models were used to demonstrate the biosorption process in the

Table 2 Diffusive kinetic models

\begin{tabular}{llc}
\hline Model & Equation & Reference \\
\hline Webber-Morris & (5) $q_{t}=k_{W M} t^{0.5}+C_{W M}$ & {$[81]$} \\
Chrastil & (6) $q_{t}=q_{e}\left(1-e^{-k_{C h} X_{0} t}\right)^{n_{C h}}$ & [82] \\
Reichenberg & $B_{t}=-0.4977-\ln (1-F(t))$ & [83] \\
& (7) $F(t)=\frac{q_{t}}{q_{e}}$ & \\
\hline
\end{tabular}


Table 3 Mathematical models that describe the equilibrium of the biosorption process

\begin{tabular}{llc}
\hline Model & Equation & Reference \\
\hline Freundlich & (8) $q_{e}=k_{F} \cdot C_{e}{ }^{1}{ }^{1} n_{F}$ & {$[84]$} \\
Langmuir & $(9) q_{e}=q_{\max } \frac{b \cdot C_{e}}{1+b \cdot C_{e}}$ & {$[85]$} \\
Sips & $(10) q_{e}=q_{\max } \frac{b_{s} \cdot C_{e}^{1 / n_{s}}}{1+b_{s} \cdot C_{e}^{1 / n_{s}}}$ & {$[86]$} \\
Redlich-Peterson & $(11) q_{e}=\frac{k_{R P} \cdot C_{e}}{1+Q \cdot C_{e} \beta}$ & {$[87]$} \\
Temkin & $(12) q_{e}=\frac{R \cdot T}{B} \cdot \ln \left(A^{\prime} C_{e}\right)$ & {$[88]$} \\
\hline
\end{tabular}

fixed-bed column. They allowed for calculating the characteristic interdependence that is referred to as the breakthrough curve. There are two important points: the breakthrough point that is the moment when the fixed-bed in a column arrangement is penetrated through and the saturation point, i.e., the time during which the concentration at the outlet of the column is comparable with the concentration of the feed solution $\left(C_{i} \approx C_{o}\right)$.

As mentioned above, various models are used for the purpose of describing the fixed-bed columns. They allow for the approximation of the experimental data by means of a proper breakthrough curve. These include the Adams and Bohart, Bed-Depth Service-Time (BDST), Thomas, Yoon and Nelson, Yan (dose-response), or the Clark model [89] (Table 4).

Each of the models adduced to describe a different course of the curve that represents the dependence of the relations of the concentrations at the input and output from the time of the biosorption process (breakthrough curves). However, it turns out that it is not only the Thomas and Yoon-and-Nelson models that are equivalent [93]. It has been proven that also the Thomas, and Adams and Bohart models represent in a graphic way exactly the same trace of the breakthrough curve, since all these models are based on the differential balance of the mass of the column of the fixed bed [96]:

$$
v \cdot \frac{\partial C}{\partial z}+\frac{\partial C}{\partial t}+\frac{(1-\varepsilon)}{\varepsilon} \cdot \rho_{p} \cdot \frac{\partial q}{\partial t}=D_{L} \cdot \frac{\partial^{2} C}{\partial z^{2}}
$$

\section{Thermodynamics of the Biosorption Process}

Biosorption is a spontaneous process with the change of the values of the thermodynamic functions [97]. In order to understand its mechanism such thermodynamic parameters ought to be calculated as: the change of free enthalpy (the Gibbs free energy) $-\Delta G^{\circ}$, change of enthalpy $\Delta H^{\circ}$, and of entropy $\Delta S^{\circ}$. The first of the mentioned can be calculated on the basis of Eq. 20:

Table 4 Models describing the fixed-bed column biosorption process

\begin{tabular}{|c|c|c|}
\hline Model & Equation & Reference \\
\hline Adams-Bohart & 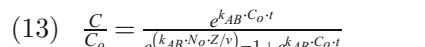 & {$[90]$} \\
\hline Bed-depth service-time & (14) $\quad t=\left(\frac{\max ^{\prime} \cdot Z}{C_{0} \cdot v}\right)-\frac{1}{C_{o} \cdot k_{B D S T}} \cdot \ln \left(\frac{C_{o}}{C}-1\right)$ & {$[91]$} \\
\hline Thomas & (15) $\quad \frac{C}{C_{o}}=\frac{1}{1+\exp \left(\left(\frac{k_{T h}}{Q}\right) \cdot\left(q_{\max } \cdot m_{s}-C_{o} \cdot V_{e f}\right)\right)}$ & {$[92]$} \\
\hline Yoon-Nelson & (16) $\quad \frac{C}{C_{o}}=\frac{e^{k} V_{N} \cdot(t-\tau)}{1+e^{k} Y N^{\prime(t-\tau)}}$ & {$[93]$} \\
\hline Yan & (17) $\frac{C}{C_{o}}=1-\frac{1}{1+\left(\frac{C_{o} \cdot V_{e f}}{a_{\max } m_{s}}\right)^{a_{Y}}}$ & [94] \\
\hline Clark & (18) $\quad \frac{C}{C_{o}}=\left(\frac{1}{1+A_{C} \cdot e^{-r t}}\right)^{1 /\left(n_{F}-1\right)}$ & {$[95]$} \\
\hline
\end{tabular}




$$
\Delta G^{0}=-R T \ln K_{0}
$$

If the value of free enthalpy is known, then the spontaneity of the process can be calculated:

- If $\Delta G<0$ the process develops spontaneously

- If $\Delta G=0$ the system is in equilibrium.

The calculation of $\Delta H^{\circ}$ and $\Delta S^{\circ}$ is possible due to the dependence described by Eq. 21:

$$
\Delta G^{0}=\Delta H^{0}-T \Delta S^{0}
$$

Equitation 22 renders the dependence between the equilibrium constant $K_{0}$, and $\Delta H^{\circ}$ and $\Delta S^{\circ}$.

$$
-R T \ln K_{0}=\Delta H^{0}-T \Delta S^{0} \rightarrow \ln K_{0}=-\frac{\Delta H^{0}}{R T}+\frac{\Delta S^{0}}{R}
$$

The presentation of the dependence in the form of the graph $K_{0}=1 / T$ facilitates the calculation of thermodynamic parameters.

The rate of biosorption depends on the temperature in which the process develops as described by the Arrhenius Eq. (23):

$$
k=A \exp \left[-E_{a} /(R T)\right]
$$

The logarithmic form of those equations allows for calculating activation energy. If its value is greater than $4-6 \mathrm{~kJ} \mathrm{~mol}^{-1}$, it reveals the chemical mechanism of the binding of the sorbate (chemisorption). If $E_{a}$ is smaller than $4 \mathrm{~kJ} \mathrm{~mol}^{-1}$, sorption takes place as a result of weaker physical interactions.

\section{Research Methodology}

\section{Experiments on Kinetics of Biosorption}

The kinetic experiments of the biosorption process are studied widely in order to determine the contact time that required to reach the sorption equilibrium and to assess the impact of process parameters such as: $\mathrm{pH}$, temperature, $C_{S}, C_{0}$ on parameters of the models (mainly $q_{\mathrm{eq}}$ and $k$ ) which are useful to assess the biosorption properties of a given biosorbent. In order to select the best model, linearization of the equation is performed for the boundary conditions $t=0$ to $t$ and $q=0$ to $q_{\mathrm{t}}$. The model is usually chosen on the basis of the value of determination coefficients. In general, most of the natural biosorbents used to remove metal ions the highest $R^{2}$ is value observed with pseudo-second order model [98].

A general experimental procedure used to study the biosorption kinetics is presented in Fig. 4. As shown, the experiments were performed in Erlenmeyer flasks containing metal ion solution (i.e., $\mathrm{Cr}(\mathrm{III})$ ) and biosorbent in water bath shaker at $150 \mathrm{rpm}$ which assures full mixing of the biomass suspended in the solution of given metal ion [99].

\section{Experiments on Equilibrium of Biosorption}

As discussed earlier, equilibrium of the biosorption process is described by sorption isotherms, showing the relationship between the mass of metal ion bound by unit mass of biosorbent and the equilibrium concentration of metal ion in the solution. The binding of metal ions on the cell 


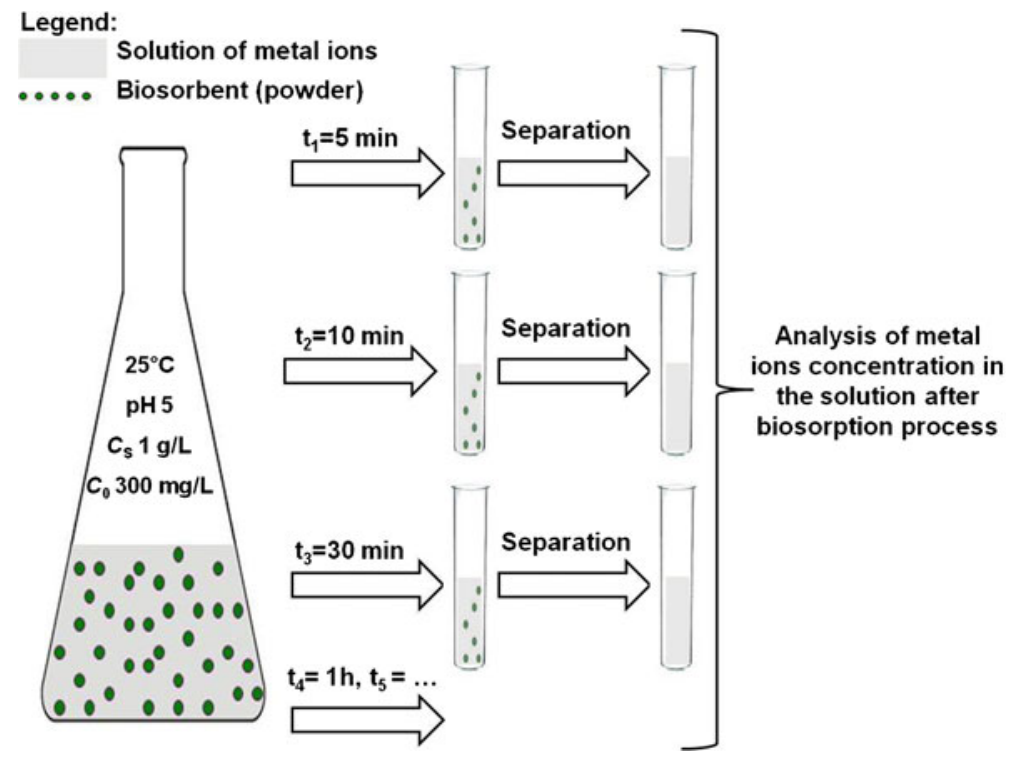

Fig. 4 General scheme for experiments on kinetics of biosorption

walls is rapid, and the process continues until the equilibrium is reached. Most often, the equilibrium between the solid and liquid phases of biosorbent is described by the Langmuir equation, seldom by Freundlich and Dubinin-Radushkevich (D-R). It is necessary to emphasize that these "models" serve only the purpose of "curve-fitting" equations rather than modeling. It is only convenient to attempt to fit Langmuir (equation of a hyperbole) because it offers physically easily interpretable parameters (constants): $q_{\max }$ and $b$. The value of $q_{\max }$ is the maximum possible amount of metal ions per gram bound on the surface of biomass by functional groups in the equilibrium state. The high value of $b$ indicates a high affinity and corresponds to the curve of the function of biosorption isotherm in the initial range. The most desirable are biosorbents with the highest possible $q_{\max }$ and the highest coefficient $b$ [3]. In practice, experimental data are substituted to linearized forms of models which describe equilibrium of the process. The parameters of these models are evaluated as well as determination coefficients $R^{2}$ which made it possible to select the model that best describes the equilibrium of the process of biosorption.

The experiments on the equilibrium of the process can be performed in Erlenmeyer flasks containing metal ion solution in a thermostated water bath shaker at $150 \mathrm{rpm}$. The $\mathrm{pH}$ level of the solutions can be adjusted with $0.1 \mathrm{M}$ solution $\mathrm{NaOH} / \mathrm{HCl}$ to the given value. In general, the optimum contact time evaluated from the kinetic experiments was used to perform these studies. The experiments should be performed for the best process parameters determined in kinetic experiments on (i.e., for macroalga Ulva prolifera it was: $25^{\circ} \mathrm{C}, \mathrm{pH} 5, C_{\mathrm{S}} 1.0 \mathrm{~g} \mathrm{~L}^{-1}[59$, 99]. The general procedure for carrying equilibrium sorption isotherms is presented in Fig. 5.

\section{Technologies and Techniques Based on Biosorption}

Literature resources indicate that the biosorption process cannot only be used for removal of toxic pollutants but also can be used for various purposes. For example, biosorption technique used for toxic metal ion removal $[3,6]$ can also be applied to the enrichment of 


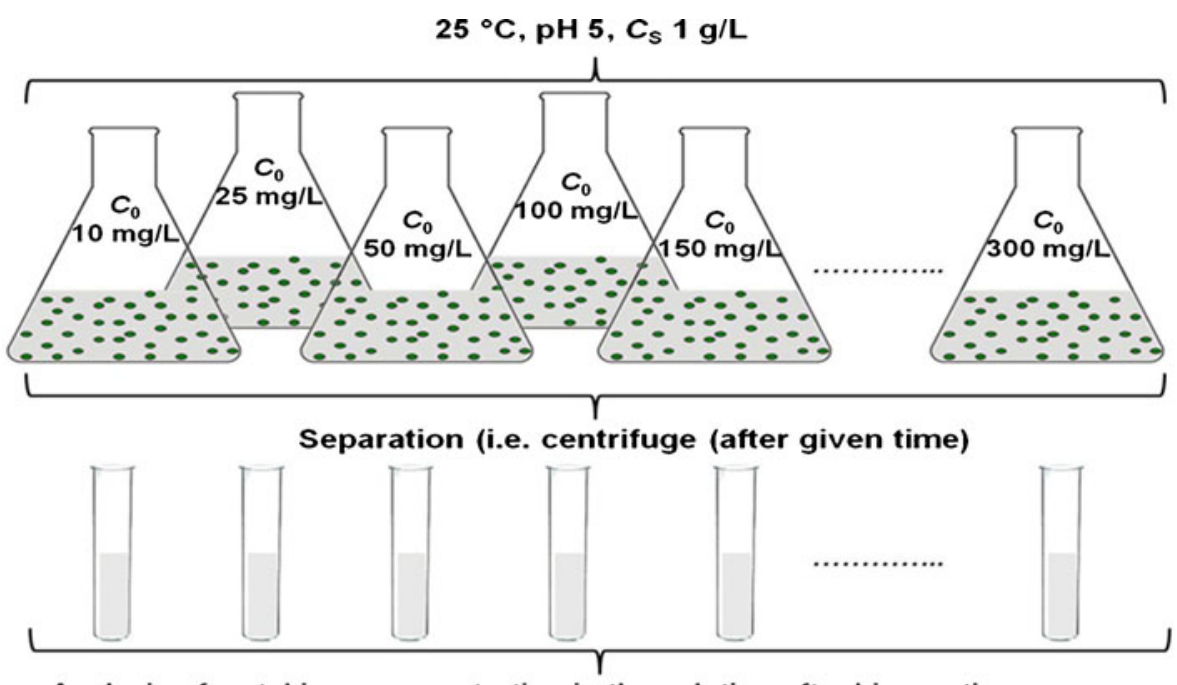

Analysis of metal ions concentration in the solution after biosorption process

Fig. 5 General scheme for experiments on equilibrium of biosorption

biomass with the trace elements which are essential to animal or plant nutrition [100] and also for the recovery of valuable metals such as silver or gold [101]. For example, literature data reported that this process was used to bind gold by brown alga Sargassum natans. It was found that the biosorption capacity of this macroalga (which is expressed in units of mole taking into account the valence of the ion) far exceeds the capacity of commonly used commercial ion exchange resins which is $0.35-5.0 \mathrm{meq} \mathrm{g}^{-1}$ [30], while for macroalga $S$. natans was 6.4 meq ions of gold per gram biomass [102].

\section{Wastewater Treatment}

Even though this technique could be useful to various purposes, the ever greater application was the removal and retrieval of contents dissolved in water or sewage. Their particular usefulness can be seen in the case of the separation of diluted but very harmful pollutants from industrial sewage such as heavy metals and some organic compounds [48, 103-105].

\section{Biological Feed Supplements and Fertilizer Components with Microelements}

Biosorption technique is mainly used in wastewater treatment, furthermore, it can be used for incorporation into biological material. Different types of biomasses enriched with microelement ions via biosorption could be used as biological feed additives to supplement livestock diet with the recommended daily intake of given microelements [100, 106-108]. Many materials, especially of plant origin or obtained from the environment, besides high natural content of minerals, have a natural property of the binding and accumulation of minerals in the process of biosorption and bioaccumulation [3].

Studies on the biosorption equilibrium of microelement ions by the biomass of green macroalgae (Pithophora varia Wille, Enteromorpha prolifera, and Vaucheria sp.) showed that they constitute a valuable biological material, which can quickly and easily be enriched with minerals, essential in animal nutrition $[50,59,70,99]$. On the basis of a maximum biosorption capacity of macroalgae (determined from the Langmuir model) towards $\mathrm{Mn}$ (II), 
$\mathrm{Zn}(\mathrm{II}), \mathrm{Cu}(\mathrm{II}), \mathrm{Co}(\mathrm{II})$, and $\mathrm{Cr}$ (III) ions and their mineral composition, enrichment coefficient of biomass - EC in biosorption in single-metal system was determined. EC is the quotient of the micronutrient content in the enriched biomass and in natural biomass. It was observed that in all studied macroalgae, the smaller content of the microelement in the natural biomass, the higher the enrichment coefficient of the biomass (Table 5) [109].

The biomass of macroalgae enriched with microelements ( $\mathrm{MA}-\mathrm{Cu}, \mathrm{MA}-\mathrm{Mn}, \mathrm{MA}-\mathrm{Zn}$, MA-Co, MA-Cr, where MA means macroalgae) was produced by the biosorption process in a single-metal system. Mixed in proper proportions, adequate to the nutritional needs of animals, it can be used as a biological feed additive with microelements. The mass of enriched algae, which should be added to $1 \mathrm{~kg}$ of feed, was calculated on the basis of the maximum biosorption capacity determined for individual microelements and on animal requirements for given minerals. It was assumed that $100 \%$ of the requirement of animals (laying hens and piglets) for the trace elements will be covered. In the case of feed for laying hens, inorganic forms of trace elements in the future can be replaced by $1.74 \mathrm{~g}$ of enriched biomass of Pithophora varia Wille, $3.47 \mathrm{~g}$ of Enteromorpha prolifera, and $4.28 \mathrm{~g}$ of Vaucheria sp., and feed for pigs, respectively: 6.46, 7.29, and $11.0 \mathrm{~g}$ of enriched biomass of macroalgae (Table 6) [109].

Zootechnical studies were performed on laying hens in order to investigate utilitarian properties of new biological feed supplements with microelements. Macroalgae enriched with $\mathrm{Mn}(\mathrm{II}), \mathrm{Zn}(\mathrm{II}), \mathrm{Cu}(\mathrm{II}), \mathrm{Co}(\mathrm{II})$, and $\mathrm{Cr}(\mathrm{III})$ ions via biosorption process, confirmed that the bioavailability of microelements from biological feed additives was higher in comparison with traditionally used inorganic salts. Hens, which were fed with enriched macroalgae, were heavier, laid larger eggs with thicker shells, which were characterized by more intense color of yolks. The eggs of hens fed with algal additives were biofortified with $\mathrm{Cu}, \mathrm{Cr}$, and $\mathrm{Mn}$ [100].

\section{Process Installation}

Dynamic processes (including biosorption) are carried out in devices with an immovable or movable biosorbent beds. Industrial application makes use of mainly vertical or horizontal cylinders connected to each other like cascades. The adsorptive is fed from the bottom of the fixed-bed, i.e., immovable column. When such a device is activated, there occurs a so-called dead time of the functioning of the column, during which the column is emptied and reloaded. The process with a movable bed is carried out continuously; the biosorbent is fed from the top, whereas the adsorptive is fed counter currently from the bottom of the column. Depending on the behaviour of the bed in the column there occurs:

Table 5 Enrichment coefficient of different macroalgae enriched with various microelements in biosorption in single-metal system [109]

\begin{tabular}{llll}
\hline Microelement & \multicolumn{3}{c}{ Enrichment coefficient of biomass } \\
\cline { 2 - 4 } & Enteromorpha prolifera & Pithophora varia Wille & Vaucheria sp. \\
\hline $\mathrm{Mn}$ & 1,458 & 37 & 14 \\
$\mathrm{Zn}$ & 2,281 & 85 & 119 \\
$\mathrm{Cu}$ & 21,177 & 1,486 & 1,693 \\
$\mathrm{Co}$ & 110,555 & 8,173 & 14,639 \\
$\mathrm{Cr}$ & 44,228 & 4,662 & 3,752 \\
\hline
\end{tabular}


Table 6 Mass of macroalgae enriched by biosorption in the single-metal system, which should be added to $1 \mathrm{~kg}$ of feed to meet $100 \%$ demand (upper limit) of the animals on the trace element [109]

\begin{tabular}{|c|c|c|c|c|c|c|c|c|}
\hline \multirow[t]{2}{*}{ Microelement } & \multicolumn{2}{|c|}{$\begin{array}{l}\text { Requirement of } \\
\text { animals }^{\mathrm{a}}\end{array}$} & \multicolumn{2}{|c|}{$\begin{array}{l}\text { Mass of enriched } \\
\text { E. prolifera }\end{array}$} & \multicolumn{2}{|c|}{$\begin{array}{l}\text { Mass of enriched } \\
P . \text { varia Wille }\end{array}$} & \multicolumn{2}{|c|}{$\begin{array}{l}\text { Mass of enriched } \\
\text { Vaucheria } \text { sp. }\end{array}$} \\
\hline & $\begin{array}{l}\text { Hens } \\
\left(\mathrm{mg} \mathrm{kg}^{-1}\right)\end{array}$ & Swine & $\begin{array}{l}\text { Hens } \\
(\mathrm{g})\end{array}$ & Swine & Hens & Swine & Hens & Swine \\
\hline $\mathrm{Cu}$ & $4.5-5.0$ & $20-165$ & 0.0926 & 3.06 & 0.0898 & 2.96 & 0.138 & 4.56 \\
\hline $\mathrm{Mn}$ & $40-60$ & $30-40$ & 2.54 & 1.70 & 1.57 & 1.04 & 2.71 & 1.81 \\
\hline $\mathrm{Zn}$ & $40-50$ & $70-150$ & 0.840 & 2.52 & 0.0818 & 2.45 & 1.53 & 4.59 \\
\hline $\mathrm{Co}$ & - & $0-0.5$ & - & 0.0119 & - & 0.00956 & - & 0.0165 \\
\hline $\begin{array}{l}\text { Total mass }(\mathrm{g}) \text { of enriched } \\
\text { biomass in } 1 \mathrm{~kg} \text { of fodder }\end{array}$ & - & - & 3.47 & 7.29 & 1.74 & 6.46 & 4.38 & 11.0 \\
\hline
\end{tabular}

${ }^{a}$ According to standards in hen and swine feeding [110, 111]

- Sorption in the movable bed

- Sorption in the fluidized bed

The laboratory research on biosorption carried out dynamically is carried out mainly in columns with fixed beds due to the complex functioning of the columns fitted with a movable layer of sorbent and the requirement for additional equipment like dispensers, specially designed shelves and chutes of the columns. A movable bed of biosorbent is applied to make the functioning of columns more effective on an industrial scale.

\section{Patents in Biosorption}

Along with research publications, a number of patents are available in the literature demonstrates biosorption process. Many patents are focused on improving the sorption capacity of biological materials, through modification or immobilization of sorbents (Table 7). Serbus et al. (1973) invented a new sorbent for treating heavy metal ions containing biological (telomic plants or algae) and water-insoluble polymeric parts [112]. Furthermore, Brierley et al. (1987) developed caustic solution $(\mathrm{NaOH}, \mathrm{KOH})$ treated raw biomass Bacillus subtilis (Patent 4690894), as treated biomass enabled enhancement in metal uptake properties [118]. In another patent, 4898827, the same group of scientists immobilized caustic-treated biomass in an insoluble organic binder [120]. Greene et al. (1991) prepared a composition by immobilizing metal ion-binding microorganisms (particularly algae) and as obtained composition was non-swelling stable material. This sorbent was employed to concentrate valuable metal ions from aqueous solutions and geothermal fluids [121]. Lakshmanan et al. (1992) prepared a bioadsorption composition (biomass encapsulated sol-gel matrix) and applied for treating uranium-contaminated wastewater and mine water [123]. Yannai et al. (1996) developed a process for metal ion removal from effluents by yeast (Saccharomyces cerevisae, Saccharomyces uvarum, and Saccharomyces lipolytica) biomass surface with sorbent regeneration (using mineral acid or chelates). The biosorption process was carried in both batch and continuous (yeasts immobilized on porous glass, purified sand, or polymers) mode [125]. Summers et al. (1996) developed a method for producing metal-ion-sorbing beads comprising of non-living biomass (i.e., peat moss) 
Table 7 Patents in biosorption

\begin{tabular}{|c|c|c|c|c|}
\hline Number & Title & $\begin{array}{l}\text { Patent origin } \\
\text { country }\end{array}$ & Inventor & Date \\
\hline 3725291 & Sorbent and method of manufacturing same & Czechoslovakia & $\begin{array}{l}\text { Serbus et al. } \\
\quad[112]\end{array}$ & 1973 \\
\hline 4021368 & $\begin{array}{l}\text { Process of treating mycelia of fungi for retention of } \\
\text { metals }\end{array}$ & Czechoslovakia & $\begin{array}{l}\text { Nemec et al. } \\
\text { [113] }\end{array}$ & 1977 \\
\hline 4067821 & Method of treating a biomass & Czechoslovakia & $\begin{array}{l}\text { Votapek et } \\
\text { al. [114] }\end{array}$ & 1978 \\
\hline 4293333 & Microbiological recovery of metals & USA & Drobot [115] & 1981 \\
\hline 4289531 & Process for recovering precious metals & USA & $\begin{array}{l}\text { Lechavelier } \\
\text { et al. [116] }\end{array}$ & 1981 \\
\hline 4320093 & Separation of uranium by biosorption & Canada & $\begin{array}{l}\text { Volesky et } \\
\text { al. [117] }\end{array}$ & 1981 \\
\hline 4690894 & $\begin{array}{l}\text { Treatment of microorganisms with alkaline solution } \\
\text { to enhance metal uptake properties }\end{array}$ & USA & $\begin{array}{l}\text { Brierley et } \\
\text { al. [118] }\end{array}$ & 1987 \\
\hline 4701261 & $\begin{array}{l}\text { Process for the separation of metals from aqueous } \\
\text { media }\end{array}$ & England & $\begin{array}{l}\text { Gibbs et al. } \\
\text { [119] }\end{array}$ & 1978 \\
\hline 4769223 & Biosorbent for gold & Canada & $\begin{array}{l}\text { Volesky et } \\
\text { al. [102] }\end{array}$ & 1988 \\
\hline 4898827 & Metal recovery & USA & $\begin{array}{l}\text { Brierley etal. } \\
\quad[120]\end{array}$ & 1990 \\
\hline 5055402 & $\begin{array}{l}\text { Removal of metal ions with immobilized metal ion- } \\
\text { binding microorganisms }\end{array}$ & USA & $\begin{array}{r}\text { Greene et } \\
\text { al.[121] }\end{array}$ & 1991 \\
\hline 5152969 & $\begin{array}{l}\text { Processes to recover and reconcentrate gold from its } \\
\text { ores }\end{array}$ & USA & $\begin{array}{l}\text { Kleid et al. } \\
\quad[122]\end{array}$ & 1992 \\
\hline 5084389 & $\begin{array}{l}\text { Bioadsorption composition and process for } \\
\text { production thereof }\end{array}$ & Canada & $\begin{array}{l}\text { Lakshmanan } \\
\text { et al. [123] }\end{array}$ & 1992 \\
\hline 5460791 & $\begin{array}{l}\text { Method for adsorbing and separating heavy metal } \\
\text { elements by using a tannin adsorbent and method of } \\
\text { regenerating the adsorbent }\end{array}$ & Japan & $\begin{array}{l}\text { Shirato et al. } \\
\text { [124] }\end{array}$ & 1995 \\
\hline 5538645 & $\begin{array}{l}\text { Process for the removal of species containing metallic } \\
\text { ions from effluents }\end{array}$ & Israel & $\begin{array}{l}\text { Yannai et al. } \\
\text { [125] }\end{array}$ & 1996 \\
\hline 5578547 & Bead for removing dissolved metal contaminants & USA & $\begin{array}{l}\text { Summers et } \\
\text { al. [126] }\end{array}$ & 1996 \\
\hline 5648313 & Method for production of adsorption material & Germany & Pohl [127] & 1997 \\
\hline 5789204 & Biosorbent for heavy metals prepared from biomass & South Korea & $\begin{array}{l}\text { Kogtev et al. } \\
\quad[128]\end{array}$ & 1998 \\
\hline 5750065 & Adsorption of PCBs using biosorbents & USA & $\begin{array}{c}\text { Kilbane } \\
\text { [129] }\end{array}$ & 1998 \\
\hline 5976847 & $\begin{array}{l}\text { Hydrophilic urethane binder immobilizing organisms } \\
\text { having active sites for binding noxious materials }\end{array}$ & USA & $\begin{array}{l}\text { Hermann } \\
\text { [130] }\end{array}$ & 1999 \\
\hline 6395143 & Biosorption system & England & $\begin{array}{r}\text { McHale et } \\
\text { al. [131] }\end{array}$ & 2002 \\
\hline 6402953 & Adsorption means for radionuclides & Russia & $\begin{array}{l}\text { Gorovoj et } \\
\text { al. [132] }\end{array}$ & 2002 \\
\hline 6579977 & Biosorbents and process for producing the same & Germany & $\begin{array}{l}\text { Pieschel et } \\
\text { al. [133] }\end{array}$ & 2003 \\
\hline 6786336 & $\begin{array}{l}\text { Composite biosorbent for treatment of waste aqueous } \\
\text { system(s) containing heavy metals }\end{array}$ & USA & $\begin{array}{l}\text { Boddu et al. } \\
\quad[134]\end{array}$ & 2004 \\
\hline 20060070949 & $\begin{array}{l}\text { Process and plant for the removal of metals by } \\
\text { biosorption from mining or industrial effluents }\end{array}$ & Chile & $\begin{array}{l}\text { Tadic et al. } \\
\quad[135]\end{array}$ & 2006 \\
\hline
\end{tabular}


Table 7 (continued)

\begin{tabular}{|c|c|c|c|c|}
\hline Number & Title & $\begin{array}{l}\text { Patent origin } \\
\text { country }\end{array}$ & Inventor & Date \\
\hline 7951578 & Bacterial strain for a metal biosorption process & Chile & $\begin{array}{r}\text { Cotoras et } \\
\text { al. }[136]\end{array}$ & 2011 \\
\hline 20070202588 & $\begin{array}{l}\text { Petroleum biosorbent based on strains of bacteria and } \\
\text { yeast }\end{array}$ & Russia & $\begin{array}{l}\text { Khabibullina } \\
\text { et al. [137] }\end{array}$ & 2007 \\
\hline 20080169238 & $\begin{array}{l}\text { Biosorption system produced from biofilms supported } \\
\text { in faujasite (FAU) Zeolite, process obtaining it and } \\
\text { its usage for removal of hexavalent chromium } \\
(\mathrm{Cr}(\mathrm{VI}))\end{array}$ & Portugal & $\begin{array}{l}\text { Simões et al. } \\
\text { [138] }\end{array}$ & 2008 \\
\hline 7658849 & $\begin{array}{l}\text { Use of Rhizopus stolonifer (Ehrenberg) Vuillemin in } \\
\text { methods for treating industrial wastewaters } \\
\text { containing dyes }\end{array}$ & Italy & $\begin{array}{l}\text { Prigione et } \\
\text { al. [139] }\end{array}$ & 2010 \\
\hline 7790031 & $\begin{array}{l}\text { Use of Cunninghamella elegans lendner in methods } \\
\text { for treating industrial wastewaters containing dyes }\end{array}$ & Italy & $\begin{array}{l}\text { Prigione et } \\
\text { al. [140] }\end{array}$ & 2010 \\
\hline 7935257 & $\begin{array}{l}\text { Use of Rhizomucor pusillus (lindt) schipper in } \\
\text { methods for treating industrial wastewaters } \\
\text { containing dyes }\end{array}$ & Italy & $\begin{array}{l}\text { Prigione et } \\
\text { al. [141] }\end{array}$ & 2011 \\
\hline 20110269169 & $\begin{array}{l}\text { Pseudomonas alcaliphila MBR and its application in } \\
\text { bioreduction and biosorption }\end{array}$ & China & $\begin{array}{l}\text { Li et al. } \\
\quad[142]\end{array}$ & 2011 \\
\hline
\end{tabular}

immobilized by sodium silicate or polysulfone binder [126]. In another invention, Hermann (1999) developed a composite material by using biomass particles. This material is composed of a hydrophilic urethane binder containing immobilized microorganisms and employed to treat metal ions present in waste streams [130]. Furthermore, in another invention, Pieschel et al. (2003) developed phosphorylated cellulose containing material by using phosphoric acid or ammonium phosphate in the presence of urea. As modified biosorbent exhibited an improved mechanical strength, and this was used to treat heavy metals from aqueous solutions [133]. Using ceramic material as substrate Boddu et al. (2004) prepared an innovative composite biosorbent, chitosan-coated substrate. The proposed composite biosorbent was used to remove a number of metal ions including $\mathrm{As}(\mathrm{V}), \mathrm{As}(\mathrm{III}), \mathrm{Cu}(\mathrm{II}), \mathrm{Cr}(\mathrm{VI}), \mathrm{Ni}(\mathrm{II}), \mathrm{Pb}(\mathrm{II})$, and $\mathrm{Hg}$ (II) from aqueous solutions [134]. In a recent invention, a biosorption system composed of a bacterial biofilm of Arthrobacter viscosus supported in synthetic faujasite zeolite was developed by Simões et al. (2008). As prepared biofilm enables reduction of $\mathrm{Cr}(\mathrm{VI})$ to $\mathrm{Cr}(\mathrm{III})$ and subsequent removal of $\mathrm{Cr}(\mathrm{III})$ by ion exchange [138]. Along with the above-discussed patents on metal ion removal in a recent invention, Khabibullina et al. (2007) developed a biosorbent to remove petroleumbased contamination from water. The sorbent was developed by immobilizing microorganisms onto a hydrophobic sorbent, where the microorganisms reach a concentration of $20-30 \%$ of the mass of the biosorbent. This biosorbent was employed in purification of water contaminated by petroleum-based products using ecologically non-toxic strains of bacteria and yeasts [137].

The most important aspect in the biosorption process is the separation of the biomass from the aqueous solution after sorption. In this perspective, several patents were filed which demonstrates the improvement of the separation of biomass after biosorption process. Nemec et al. (1977) invented a granulated product using mycelia of microorganisms and 
employed for separation of metal ions (uranium, radium, lead, etc.) from solutions. The biomass was stiffened by polymerization and granulated to achieve higher mechanical rigidity which allows an easier separation from the solution [143]. In another invention (Votapek et al. 1978), a method of stiffening a biomass comprising of mycelium fungi was reported. This procedure includes three steps: dispersing of biomass in a non-polar solvent, agglomeration, and stiffening the agglomerated mixture by addition of a catalyst [144]. Furthermore, Gibbs et al. (1978) reported magnetic separation technology, which is used to separate the biomass after the sorption process. In this invention, highly toxic low concentrated metal ions, e.g., uranium, were removed by using yeasts and magnetic separation technique [149]. Pohl et al. (1997) proposed the preparation of a biosorbent based on brown algae [127]. In another invention, patent 6395143 (McHale et al. 2002), an electrodiffusionassisted system was developed; this system consists of a process for separating biosorbent and sorbate. The system is composed of a waste biomass enclosed within a membrane system coupled to an electrode. The system was applicable to remove dyes, heavy metal, and radionuclide ions and other pollutants from aqueous solutions [131].

In addition to the aforementioned patents, several inventions are filed on application of biosorption technology for recovering precious metal ions. Due to the economic importance, recovery of precious metals by biosorption process has gained much attention. In this perspective, Drobot (1981) invented a method for recovering valuable metals from industrial wastewater by using the dead fungus (particularly Cladosporium, Penicillium, Trichoderma, Black Mycelium, and Aureobasidium) [145]. Recovery of precious metals (platinum, rhodium, palladium, ruthenium, iridium, gold, silver, zinc, aluminum, iron, copper, tin, and nickel) using proteinaceous materials like feathers, hair, hoof meal, and horn meal was developed by Lechavelier and Drobot (1981) [146]. In an invention, Volesky et al. (1981) described removal of radioactive heavy metal ions, like uranium and thorium, using genus Rhizopus (i.e., Rhizopus arrhizus) [147]. However, due to the economic importance of precious metal ion gold, several inventions are focused on gold recovery by using biosorption process. For example, patent 4769223 described gold biosorption onto seaweed (genus Sargassum) [132]. Furthermore, Kleid et al. (1992) proposed recovery of gold from its ores with a diversity of microorganisms, including Chromobacterium violaceum and Chlorella vulgaris [152].

Shirato et al. (1995) used tannin adsorbent for separating several heavy metals (like actinides, lead, cadmium, mercury, iron) with possible desorption by changing the $\mathrm{pH}$ of the solution, this invention also demonstrated a method for regenerating adsorbent [124]. Kogtev et al. (1998) developed polyaminosaccharide sodium phosphate-based biosorbent, using waste microbial biomass (Aspergillus, Penicillium, Trichoderma, or Micrococcus genus), for heavy metal ion removal [128]. In another invention, Kilbane (1998) prepared imprinted proteins by using inexpensive protein sources. As obtained biosorbent was used for selective adsorption of polychlorinated biphenyls (PCBs) from PCB-contaminated oils [129]. Gorovoj et al. (2002) prepared a biosorptive material from fungal biomass containing chitin for the treatment of liquid radioactive wastes generated from the nuclear industry and power stations [132]. Tadic et al. (2006) in a patent 20060070949 reported a method and developed a bioremediation plant to remove metal ions by biosorption from mining or industrial effluents. This method is composed of one pretreatment step (precipitation, solvent extraction, or solvent extraction on emulsified membranes) and continuous metal ion removal by biosorption in a series of reactors [135]. In an invention, a new bacterial strain of Bacillus sp. was utilized for biosorption of metal ions [136]. Prigione et al.'s (2010, 2011) group utilized several microorganisms, like Rhizopus stolonifer [139], Cunninghamella elegans [140], and Rhizomucor pusillus [141] for dyes removal from industrial wastewaters. 
In a recent invention, Li et al. (2011) used Pseudomonas alcaliphila MBR CGMCC 2318 which was able to reduce and sorb metal and nonmetal ions [142].

\section{Industrial Application of Biosorption Technology}

In the last decade (Web of Science 2002-2012), a vast number of publications (more than 1,500 manuscripts with the word "biosorption" in the title) including research articles, reviews, short communications, and comments were generated on the biosorption technology. However, it was found that most of this research on biosorption was carried in a laboratory scale, using batch tank reactors or packed minicolumns. In general, transfer of knowledge from laboratory scale to industrial applications is a relatively slow process. Thus very limited numbers of industrial processes or products in biosorption area have been implemented.

The first pilot plant installations of biosorption technology was appeared in the USA and Canada [143]. In the 1990s, several commercial biosorbents have been proposed for the removal of heavy metal ions from industrial or mining wastewaters. Among them BIO-FIX, AMT-BIOCLAIM ${ }^{\mathrm{TM}}$, AlgaSORB ${ }^{\mathrm{TM}}$ are the most popular sorbents prepared by immobilization of specific biomaterials.

US Bureau of Mines (Golden, CO, USA) proposed a new sorbent namely BIO-FIX beads for the heavy metal ions removal from industrial wastewaters, acid mine drainage (AMD) waters and ground waters. These sorbents incorporated a biomass of cyanobacteria (Spirulina), yeasts, algae or plants (Lemna sp., Sphagnum sp.), immobilized in polymeric (polysulphone, polyethylene, polypropylene) porous beads [144]. This sorbent was used in packed bed and fluidized bed columns as well as in simple low-maintenance troughs system. Screening tests have shown that this sorbent is very efficient and useful in treatment of waters containing heavy metal ions in the range of micrograms per liter (initial concentration of around $50 \mathrm{mg} \mathrm{L}^{-1}$ ). In addition, long-term usage of BIO-FIX beads in repeated sorptiondesorption cycles (with mineral acids as eluents) have shown that this sorbent is very effective and stable (over $9 \%$ of sorption capacity after 200 cycles). Pilot-plant tests with three columns, each contained $284 \mathrm{~L}$ of beads (over 3.8 million liters of treated waters), confirmed a very good sorbent performance [145].

Advanced Mineral Technologies, Inc. (AMT) has employed a new sorbent, AMTBIOCLAIM $^{\mathrm{TM}}$, obtained from industrial fermentation process (i.e., Bacillus subtilis) [146, 147]. Granular biomass, called metal recovery agent, about $0.1 \mathrm{~mm}$ size, effectively removed heavy metal ions from wastewater (efficiency over $99 \%$ especially for $\mathrm{Ag}, \mathrm{Cd}, \mathrm{Cu}$, $\mathrm{Pb}$, and $\mathrm{Zn}$ ) and recovered precious metals ( $\mathrm{Au}$ from gold cyanide solutions with uptake $394 \mathrm{mg} \mathrm{g}^{-1}$ ). Economic analysis indicated that the process is $50 \%$ cheaper than chemical precipitation and about $28 \%$ than ion exchange [148].

An algal biosorbent AlgaSORB ${ }^{\mathrm{TM}}$, Chlorella vulgaris immobilized on silica gel polymer matrix, has been developed by Bio-Recovery System, Inc. (Las Cruces, USA) and this sorbent was employed to treat heavy metal ions from diluted solutions $\left(1-100 \mathrm{mg} \mathrm{g}^{-1}\right)$. This biological ion-exchange resin was able to bind both metallic cations and metallic oxoanions and could be competitive to commercial ion-exchange resins [149]. B.V. SORBEX, Inc. (Montreal, Canada) started by popular biosorption researcher Bohumil Volesky offered a commercial sorbent, metal-binding biomass, BV-SORBEX ${ }^{\mathrm{TM}}$. Biosorbents family included powders and granules of size between 0.1 and $3 \mathrm{~mm}$, consisting of algae $(S$. natans, $A$. nodosum, H. opuntia, P. pamata, C. Crispus, and C. vulgaris) [6]. Uptake of metal ions by this sorbent was independent on solution concentration and was able to remove metal ions 
from concentrated or diluted solutions with high efficiency (over $99 \%$ ) (www.bvsorbex.net/ sxProcess.pdf [150]). MetaGeneR and RAHCO Bio-Beads were two other commercial biosorbents which could be used as effective materials for removal of heavy metal ions from wastewaters (mainly electroplating and mining industry) [151, 152].

\section{Pilot Scale Application of Biosorption Process}

Biosorption process has extensive experience in laboratory scale (batch and column). However, to make this technology available to industrial scale several researchers made attempts to test this process in pilot plant-scale studies. In this perspective, Artola et al. (2001) tested a three-zone contact-settling small pilot plant for $\mathrm{Cu}(\mathrm{II})$ removal by using anaerobically digested sludge. Results obtained from pilot studies were similar to those from batch equilibrium experiments. $\mathrm{Cu}$ /sludge feed ratio about $90 \mathrm{mg} \mathrm{Cu}$ (II) per gram of total solids allowed efficient heavy metal ion removal from the solution with the best quality of effluent [153]. In another investigation, Tigini et al. (2011) employed C. elegans biomass in $200 \mathrm{~L}$ of pilot plant installation for dye removal, consisting of a two-unit operation: biosorption and sedimentation. Obtained results showed that biosorption was an effective process for the removal of different pollutants from spent baths and wastewaters [154]. Zouboulis et al. (2002) proposed a process of biosorptive floatation for the removal of heavy metal ions (i.e., nickel, copper, and zinc ions) from aqueous solutions using grape stalks, a by-product of the winery industry. In pilot-scale experiments, two feed solutions containing different metal ion concentrations (low and high level) were contacted in counter-current mode with a biomass. This configuration allowed improvement of the performance of the biosorbent. Floatation separation experiments were conducted in 10-L columns. The removal of all tested metal ions was found to be satisfactory. The regenerated biomass was used in the second cycle [155].

\section{Conclusions and Future Perspectives}

This review has attempted to cover a wide range of publications and patents published so far on the biosorption technology and made an attempt to provide state-of-art biosorption technology. Biosorption has attracted a considerable attention of academic, research, and industries due to its increased applications in various fields. Since naturally available low-cost biomaterials have been utilized for this purpose, it has been in focus in recent years. In this perspective, a number of publications have evolved, which discuss a wide range of biosorption applications including, toxic pollutant removal, feed additives, and fertilizers. A survey on the general overview of published articles on biosorption technology were presented in Fig. 6a-e. It can be clearly seen that in the years 2002-2011, there is an increased interest in biosorption technology (Fig. 6a). Along with this, it was observed that most of the studies were focused on the examination of kinetic and equilibrium of biosorption (Fig. 6b). Further as a sorbate, heavy metals are chosen for investigation biosorption process (Fig. 6c). It was further found that among different biosorbents, most studies utilized algae as biosorbent (Fig. 6d). Papers in the literature on the performance of biosorption concern mainly on the batch biosorption process, than continuous biosorption and finally biosorption in reactor.

Even though a large number of laboratory studies were carried on biosorption process, still several technical and scientific issues should be solved to bring this technology into commercialization. Therefore further research is required to meet the industrial demands. Based on this, the following future perspectives can be made: 

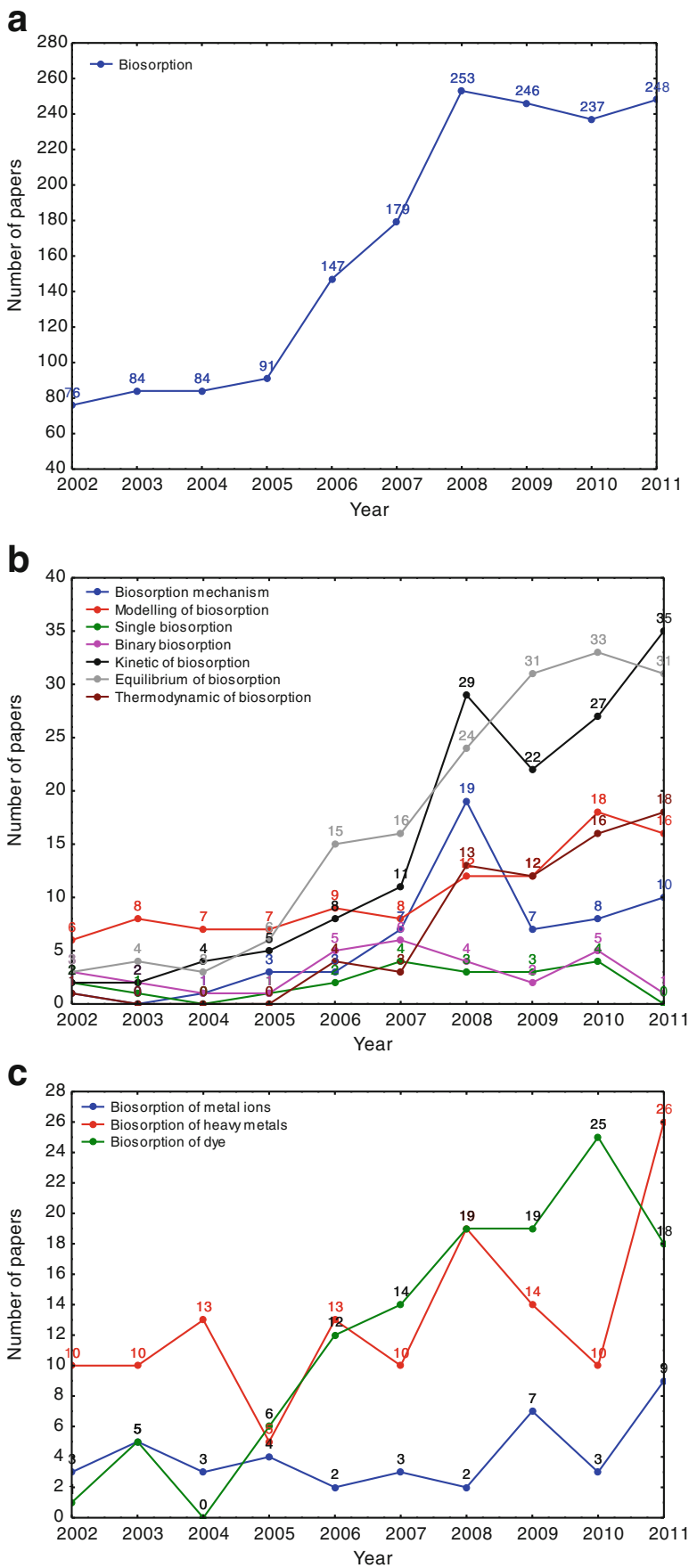

Fig. 6 Number of papers on biosorption with a "biosorption" word in the topic, b different "key words" in the topic, c different "key words" in the topic: type of sorbate, d different "key words" in the topic: type of biosorbent, e different "key words" in the topic: kind of biosorption process (source: Web of Knowledge) 

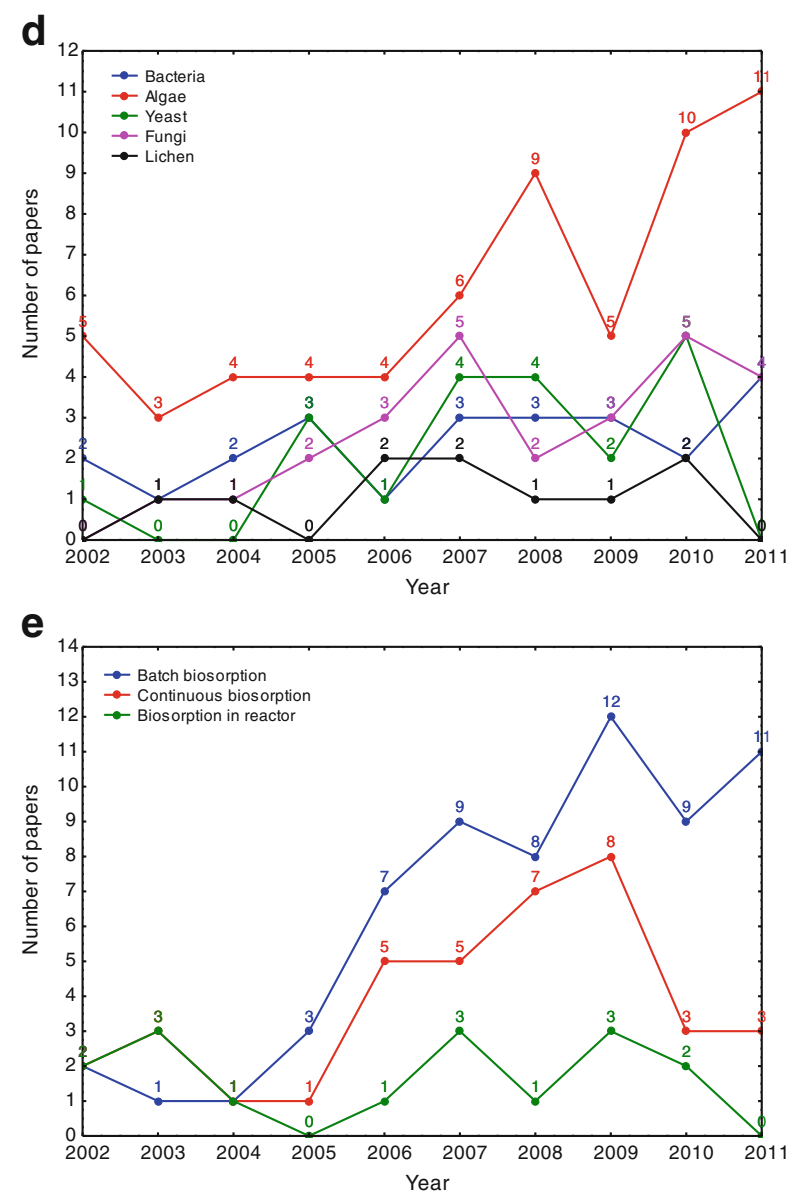

Fig. 6 (continued)

- Even though a large number of biosorbents were available, still it is essential to prepare more efficient, economic, and selective biosorbents.

- A number of mathematical models were used for the single metal biosorption process; however, elaboration of new, improved, and simplified mathematical models for the description of multi-sorbate systems is required.

- To obtain the best performance of biosorption process, it is essential to identify the biosorption mechanism in relation to the class of the biosorbents.

- Even though a large number of patents and publications were available, the process is still in laboratory-scale, which should be brought to commercialization.

- For the application of biosorption technology in industrial scale, economic analyses are required to obtain the overall cost of the sorbent and biosorption process to treat a large number of wastewater.

- Further attention should be given to the application of biosorption technology in product recovery - separation, purification, and recovery — of biomolecules (i.e., pharmaceuticals) from mixtures (i.e., proteins, sterides, etc.). 
- Preconcentration of analytes at low-level concentration is an important aspect in analytical chemistry, biosorption technology; using low-cost biosorbents will be useful, and studies are encouraged in this field.

- The recent most advantageous application of biosorption is in the field of fertilizer and feed components. By using the biomass as the carrier of nutrients (microelement cations) in the nutrition of plants and animals, biological fertilizer and feed components can be manufactured by biosorption technology with low cost.

Acknowledgments The work was supported by The National Centre for Research and Development in Poland, project no. N R05 001410 and Polish National Science Centre, project no. UMO-2012/05/E/ST8/ 03055. The authors would like to thank D.H.K. Reddy for his support with many constructive comments and useful discussions.

Open Access This article is distributed under the terms of the Creative Commons Attribution License which permits any use, distribution, and reproduction in any medium, provided the original author(s) and the source are credited.

\section{References}

1. Gadd, G. M. (2009). Journal of Chemical Technology \& Biotechnology, 84, 13-28.

2. Schiewer, S., \& Volesky, B. (1995). Environmental Science and Technology, 29, 3049-3058.

3. Davis, T. A., Volesky, B., \& Mucci, A. (2003). Water Research, 37, 4311-4330.

4. Kuyucak, N. (1990). Feasibility of biosorbents application. In B. Volesky (Ed.), Biosorption of heavy metals (pp. 371-378). Boca Raton: CRC Press.

5. Kratochvil, D., \& Volesky, B. (1998). Water Research, 32, 2760-2768.

6. Volesky, B. (1990). Biosorption and biosorbents. In B. Volesky (Ed.), Biosorption of heavy meatals (pp. 3-5). Boca Raton: CRC Press.

7. Volesky, B. (2003). Potential of biosorption. In B. Volesky (Ed.), Sorption and biosorption (pp. 5-12). Montreal: BV Sorbex, Inc.

8. Al-Masri, M. S., Amin, Y., Al-Akel, B., \& Al-Naama, T. (2010). Applied Biochemistry and Biotechnology, 160, 976-987.

9. Witek-Krowiak, A., \& Reddy, D. H. K. (2013). Bioresource Technology, 127, 350-357.

10. Witek-Krowiak, A., Szafran, R. G., \& Modelski, S. (2011). Desalination, 265, 126-134.

11. Reddy, D. H. K., Lee, S.-M., \& Seshaiah, K. (2012). Water, Air, and Soil Pollution, 223, 5967-5982.

12. Blázquez, G., Martín-Lara, M. A., Tenorio, G., \& Calero, M. (2011). Chemical Engineering Journal, $168,170-177$.

13. Volesky, B. (2007). Water Research, 41, 4017-4029.

14. Manique, M. C., Faccini, C. S., Onorevoli, B., Benvenutti, E. V., \& Caramão, E. B. (2012). Fuel, 92, 56-61.

15. Acheampong, M. A., Pakshirajan, K., Annachhatre, A. P., \& Lens, P. N. L. (2013). Journal of Industrial and Engineering Chemistry, 19, 841-848.

16. Reddy, D. H. K., Ramana, D. K. V., Seshaiah, K., \& Reddy, A. V. R. (2011). Desalination, 268, 150-157.

17. Reddy, D. H. K., Seshaiah, K., Reddy, A. V. R., Rao, M. M., \& Wang, M. C. (2010). Journal of Hazardous Materials, 174, 831-838.

18. Reddy, D. H. K., Seshaiah, K., Reddy, A. V. R., \& Lee, S. M. (2012). Carbohydrate Polymers, 88, 1077-1086.

19. Reddy, D. H. K., Harinath, Y., Seshaiah, K., \& Reddy, A. V. R. (2010). Chemical Engineering Journal, $162,626-634$.

20. Witek-Krowiak, A. (2013). European Journal of Wood and Wood Products, 71, 227-236.

21. Witek-Krowiak, A. (2011). Chemical Engineering Journal, 171, 976-985.

22. Khoramzadeh, E., Nasernejad, B., \& Halladj, R. (2013). Journal of the Taiwan Institute of Chemical Engineers, 44, 266-269.

23. Ma, W., \& Tobin, J. M. (2003). Water Research, 37, 3967-3977.

24. Alinnor, I. J. (2007). Fuel, 86, 853-857.

25. Cho, H., Oh, D., \& Kim, K. (2005). Journal of Hazardous Materials B, 127, 187-195. 
26. Erol, M., Küçükbayrak, S., Ersoy-Meriçboyu, A., \& Ulubaş, T. (2005). Energy Conversion and Management, 46, 1319-1331.

27. Chojnacka, K., \& Michalak, I. (2009). GLOBAL NEST: The International Journal, 11, 205-217.

28. Jeffers, T. H., \& Corwin, R. R. (1993). In A. E. Torma, M. L. Apel, \& C. L. Brierley (Eds.), Biohydrometallurgical technologies, Proceedings of the International Biohydrometallurgy Symposium, Wastewater remediation using immobilized biological extractants (pp. 1-14). Warrendale: The Minerals, Metals and Materials Society.

29. Mahan, C. A., \& Holcombe, J. A. (1992). Analytical Chemistry, 64, 1933-1939.

30. Fourest, E., \& Roux, J. C. (1994). FEMS Microbiology Reviews, 14, 325-332.

31. Baysal, Z., Cinar, E., Bulut, Y., Alkan, H., \& Dogru, M. (2009). Journal of Hazardous Materials B, 161, 62-67.

32. Selatnia, A., Madani, A., Bakhti, M. Z., Kertous, L., Mansouri, Y., \& Yous, R. (2004). Minerals Engineering, 17, 903-911.

33. Arica, M. Y., Bayramoglu, G., Yilmaz, M., Genc, O., \& Bektas, S. (2004). Journal of Hazardous Materials B, 109, 191-199.

34. Aksu, Z. (2005). Process Biochemistry, 40, 997-1026.

35. Niu, H. (2002). Ph.D. thesis, McGill University, Montreal.

36. Kratochvil, D. (1997). Ph.D. thesis, McGill University, Montreal.

37. Giles, C. H., \& Hassan, A. S. A. (1958). Journal of The Society of Dyers and Colourists, 74, 846-857.

38. Giles, C. H., Hassan, A. S. A., \& Subramanian, R. V. R. (1958). Journal of The Society of Dyers and Colourists, 74, 681-688.

39. Milot, C., Guibal, E., Roussy, J., \& LeCloiree, P. (1997). In F. M. Doyle, N. Arbiter, \& N. Kuyucak (Eds.), Mineral processing and extractive metallurgy review, chitosan gel beads as a new biosorbent for molybdate removal (pp. 293-308). New York: Gordon and Breach.

40. Guibal, E., Milot, C., \& Roussy, J. (1999). Water Environment Research, 71, 10-17.

41. Dambies, L., Roze, A., Roussy, J., \& Guibal, E. (1999). Process Metallurgy, 9, $277-287$.

42. Crist, R. H., Martin, J. R., \& Crist, D. R. (1999). Environmental Science and Technology, 33, 2252-2256.

43. Yang, J., \& Volesky, B. (1999). Environmental Science and Technology, 33, 4079-4085.

44. Esposito, A., Pagnanelli, F., \& Vegliò, F. (2002). Chemical Engineering Science, 57, 307-313.

45. Gavrilescu, M. (2004). Engineering in Life Sciences, 3, 219-232.

46. Talaro, K. P., \& Talaro, A. (2002). Foundations in microbiology. Blacklick: McGraw-Hill College.

47. Chojnacka, K., Chojnacki, A., \& Górecka, H. (2005). Chemosphere, 59, 75-84.

48. Volesky, B., \& Holan, Z. R. (1995). Biotechnology Progress, 11, 235-250.

49. Kalijadis, A. M., Vukčević, M. M., Jovanović, Z. M., Laušević, Z. V., \& Laušević, M. D. (2011). Journal of The Serbian Chemical Society, 76, 757-768.

50. Michalak, I., \& Chojnacka, K. (2010). Engineering in Life Sciences, 10, $209-217$.

51. Sheng, P. X., Ting, Y. P., Chen, J. P., \& Hong, L. (2004). Journal of Colloid and Interface Science, 275 , $131-141$.

52. Percival, E. G. V., \& McDowell, R. H. (1967). Chemistry and enzymology of marine algal polysaccharides. London: Academic Press.

53. Nurchi, V. M., Crisponi, G., \& Villaescusa, I. (2010). Coordination Chemistry Reviews, 254, 2181-2192.

54. Murphy, V., Hughes, H., \& McLoughlin, P. (2007). Water Research, 41, 731-740.

55. Pons, M. N., Bonte, S. L., \& Potier, O. (2004). Journal of Biotechnology, 113, 211-230.

56. Fourest, E., \& Volesky, B. (1996). Environmental Science and Technology, 30, 277-282.

57. Figueira, M. M., Volesky, B., \& Mathieu, H. J. (1999). Environmental Science and Technology, 33, $1840-1846$.

58. Reategui, M., Maldonado, H., Ly, M., \& Guibal, E. (2010). Applied Biochemistry and Biotechnology, $162,805-822$.

59. Michalak, I., \& Chojnacka, K. (2009). World Journal of Microbiology \& Biotechnology, 25, 997-1005.

60. Pethkar, A. V., Kulkarni, S. K., \& Paknikar, K. M. (2001). Bioresource Technology, 80, 211-215.

61. Park, D., Yun, Y.-S., \& Park, J. M. (2008). Journal of Colloid and Interface Science, 317, 54-61.

62. Li, K., Wang, Q., Dang, Y., et al. (2012). Acta Chimica Sinica, 70, 929-937.

63. Xie, P., Hao, X., Mohamad, O. A., Liang, J., \& Wei, G. (2013). Applied Biochemistry and Biotechnology, 169, 570-587.

64. Abu Al-Rub, F. A., El-Naas, M. H., Ashour, I., \& Al-Marzouqi, M. (2006). Process Biochemistry, 41, 457-464.

65. Pagnanelli, F., Trifoni, M., Beolchini, F., Esposito, A., Toro, L., \& Vegliò, F. (2001). Process Biochemistry, 37, 115-124.

66. Aksu, Z., \& Dönmez, G. (2006). Process Biochemistry, 41, 860-868.

67. Mohapatra, H., \& Gupta, R. (2005). Bioresource Technology, 96, 1387-1398. 
68. Pradhan, S., \& Rai, L. C. (2001). BioMetals, 14, 67-74.

69. Chong, K. H., \& Volesky, B. (1996). Biotechnology and Bioengineering, 49, 629-638.

70. Michalak, I., \& Chojnacka, K. (2008). Journal of the Science of Food and Agriculture, 88, 1178-1186.

71. Han, X., Shan Wong, Y., Hung Wong, M., \& Fung Yee Tam, N. (2008). Journal of Hazardous Materials, 158, 615-620.

72. Pulsawat, W., Leksawasdi, N., Rogers, P. L., \& Foster, L. J. R. (2003). Biotechnology Letters, 25, 1267-1270.

73. Filipović-Kovačević, Ž., Sipos, L., \& Briški, F. (2000). Food Technology and Biotechnology, 38, $211-216$.

74. Ahuja, P., Gupta, R., \& Sabena, R. K. (1999). Process Biochemistry, 34, 77-85.

75. Tobin, J. M., Cooper, D. G., \& Neufeld, R. J. (1987). Biotechnology and Bioengineering, 30, 882-886.

76. Kuyucak, N., \& Volesky, B. (1989). Biotechnology and Bioengineering, 33, 809-814.

77. Crini, G., \& Badot, P. (2008). Progress in Polymer Science, 33, 399-447.

78. Lagergren, S., \& Sven, K. (1898). Vetenskapsakad Handl, 24, 1-39.

79. Ho, Y. S., Wase, D. A. J., \& Forster, C. F. (1996). Environmmental Technology, 17, 71-77.

80. Liu, Y., \& Shen, L. (2008). Biochemical Engineering Journal, 38, 390-394.

81. Weber, W. J., \& Morris, J. C. (1963). Journal of the Sanitary Engineering Division. Proceedings of the American Society of Civil Engineers, 89, 31-59.

82. Chrastil, J. (1988). International Journal of Biochemistry, 20, 683-693.

83. Sert, S., Kütahyali, C., Inan, S., Talip, Z., Çetinkaya, B., \& Eral, M. (2008). Hydrometallurgy, 90, $13-18$.

84. Freundlich, H. M. F. (1906). Zeitschrift für Physikalische Chemie, 57, 385-470.

85. Langmuir, I. (1916). Journal of the American Chemical Society, 38, 2221-2295.

86. Sips, R. (1948). The Journal of Physical Chemistry, 16, 490-495.

87. Redlich, O., \& Peterson, D. L. (1959). The Journal of Physical Chemistry, 63, 1024-1026.

88. Temkin, M. I., \& Pyzhev, V. (1940). Kinetic of ammonia synthesis on promoted iron catalyst. Acta physiochimica URSS, 12, 327-356.

89. Vijayaraghavan, K., \& Yun, Y. S. (2008). Biotechnology Advances, 26, 266-291.

90. Bohart, G. S., \& Adams, E. Q. (1920). Journal of the American Chemical Society, 42, 523-544.

91. Goel, J., Kadirvelu, K., Rajagopal, C., \& Garg, V. K. (2005). Journal of Hazardous Materials, 125, 211-220.

92. Thomas, H. C. (1944). Journal of the American Chemical Society, 66, 1664-1666.

93. Calero, M., Hernáinz, F., Blázquez, G., Tenorio, G., \& Martín-Lara, M. A. (2009). Journal of Hazardous Materials, 171, 886-893.

94. Yan, G. Y., Viraraghavan, T., \& Chem, M. (2001). Adsorption Science \& Technology, 19, $25-43$.

95. Clark, R. M. (1987). Journal of the American Water Works Association, 79, 33-131.

96. Chu, K. H. (2010). Journal of Hazardous Materials, 177, 1006-1012.

97. Witek-Krowiak, A. (2012). Chemical Engineering Journal, 192, 13-20.

98. Aksu, Z. (2001). Separation and Purification Technology, 21, 285-294.

99. Michalak, I., \& Chojnacka, K. (2010). Applied Biochemistry and Biotechnology, 160, 1540-1556.

100. Michalak, I., Chojnacka, K., Dobrzański, Z., Górecki, H., Zielińska, A., Korczyński, M., \& Opaliński, S. (2011). Journal of Animal Physiology and Animal Nutrition, 95, 374-387.

101. Vegliò, F., \& Beolchini, F. (1997). Hydrometallurgy, 44, 301-316.

102. Volesky, B., \& Kuyucak, N. (1998). Biosorbent for gold, US Patent No: 4769223

103. Klimenko, N. A., Marutovsky, R. M., Pidlisnyuk, V. V., Nevinnaya, L. V., Smolin, S. K., Kohlmann, J., \& Radeke, K.-H. (2002). Engineering in Life Sciences, 2, 317-324.

104. Crini, G. (2006). Bioresource Technology, 97, 1061-1085.

105. Das, N., Vimala, R., \& Karthika, P. (2008). Indian Journal of Biotechnology, 7, 159-169.

106. Witkowska, Z., Saeid, A., Chojnacka, K., Dobrzański, Z., Górecki, H., Michalak, I., Korczyński, M., \& Opaliński, S. (2012). American Journal of Agricultural and Biological Sciences, 7, 482-493.

107. Saeid, A., Chojnacka, K., Korczyński, M., Korniewicz, D., \& Dobrzański, Z. (2013). Journal of Applied Phycology, 25, 667-675.

108. Janeczek, M., Chojnacka, K., Yasar Toker, N., Pecka, E., Czerski, A., Witkowska, Z., Chrószcz, A., Zawadzki, W., \& Opaliński, S. (2012). Journal of Animal and Veterinary Advances, 11, 4051-4057.

109. Michalak, I. (2009). Ph.D. thesis, Wroclaw University of Technology

110. Smulikowska, S. (1996). Standards in Hen Feeding. Warsaw: PAN.

111. Smulikowska, S. (1993). Standards in Swine Feeding. Warsaw: Omnitech Press.

112. Serbus, C., Hora, K., Rezae, J., Pribil, S., Marvan, P., Krejdirik, L., et al. (1973). Sorbent and method of manufacturing same. U.S. Patent No: 3725291.

113. Nemec, P., Prochazka, H., Stamberg, K., Katzer, J., Stamberg, J., Jilek, R., et al. (1977). Process of treating mycelia of fungi for retention of metals. U.S. Patent No: 4021368.

114. Votapek, V., Marval, E., Jilek, R., \& Stamberg, K. (1978). Method of treating a biomass. U.S. Patent No: 4067821.

115. Drobot, W. (1981). Microbiological recovery of metals. US Patent No: 4293333. 
116. Lechavelier, H. A., \& Drobot, W. (1981). Process for recovering precious metals. US Patent No: 4289531.

117. Volesky, B., \& Tsezos, M. (1981). Separation of uranium by biosorption. US Patent No: 4320093.

118. Brierley, J. A., Brierley, C. L., Decker, R. F., \& Goyak, G. M. (1987). Treatment of microorganisms with alkaline solution to enhance metal uptake properties. US Patent No: 4690894.

119. Gibbs, D. F., Greenhalgh, M. E., Watson, J. H. P., Yeo, R. G., \& Ellwood, D. C. (1987). Process for the separation of metals from aqueous media. US Patent No: 4701261.

120. Brierley, J. A., Brierley, C. L., Decker, R. F., \& Goyak, G. M. (1990). Metal recovery. US Patent No: 4898827.

121. Greene, B., McPherson, R. A., Darnall, D. W., \& Gardea-Torresdey, J. L. (1991). Removal of metal ions with immobilized metal ion-binding microorganisms. US Patent No: 5055402.

122. Kleid, D. G., Kohr, W. J., \& Thibodeau, F. R. (1992) Processes to recover and reconcentrate gold from its ores. US Patent No: 5152969.

123. Lakshmanan, V. I., \& McCready, R. G. L. (1992). Bioadsorption composition and process for production thereof. US Patent No: 5084389.

124. Shirato, W., \& Kamei, Y. (1995) Method for adsorbing and separating heavy metal elements by using a tannin adsorbent and method of regenerating the adsorbent. US Patent No: 5460791.

125. Yannai, S., \& Meshulam, G. (1996). Process for the removal of species containing metallic ions from effluents. US Patent No: 5538645.

126. Summers Jr., B. L., \& Gress, L. B. (1996). Bead for removing dissolved metal contaminants. US Patent No: 5578547.

127. Pohl, P. (1997). Method for production of adsorption material. US Patent No: 5648313.

128. Kogtev, L. S., Park, J. K., Pyo, J. K., \& Mo, Y. K. (1998). Biosorbent for heavy metals prepared from biomass. US Patent No: 5789204.

129. Kilbane, J. J. (1998). Adsorption of PCB's using biosorbents. US Patent No: 5750065.

130. Hermann, P. (1999). Hydrophilic urethane binder immobilizing organisms having active sites for binding noxious materials. US Patent No: 5976847.

131. McHale, A., \& Bustard, M. (2002). Biosorption system. US Patent No: 6395143.

132. Gorovoj, L. F., \& Kosyakov, V. N. (2002). Adsorption means for radionuclides. US Patent No: 6402953.

133. Pieschel, F., Lange, E., Camacho, J., Fieseler, C., \& Ikier, H. (2003). Biosorbents and process for producing the same. US Patent No: 6579977.

134. Boddu, V. M., \& Smith, E. D. (2004). Composite biosorbent for treatment of waste aqueous system(s) containing heavy metals. US Patent No: 6786336

135. Tadic, D. C., Lozano, F. V., Zarzar Maza, M. E., \& Viedma Elicer, P. L. (2006). Process and plant for the removal of metals by biosorption from mining or industrial effluents. US Patent No: 20060070949.

136. Cotoras, D., \& Viedma, P. (2011). Bacterial strain for a metal biosorption process. US Patent No: 7951578 .

137. Mubarakovna Khabibullina, F., Borisovna Archegova, I., Alexandrovich Shubakov, A., Ednundovna Sharapova, I., Romanov, G. G., Yurievich Chernov, I., et al. (2007). Petroleum biosorbent based on strains of bacteria and yeast. US Patent No: 20070202588.

138. Simões Campos Tavares, T. M. J., \& Pontes Correia Neves, I. M. (2008). Biosorption system produced from biofilms supported in faujasite (FAU) zeolite, process obtaining it and its usage for removal of hexavalent chromium (Cr(VI)). US Patent No: 20080169238.

139. Prigione, V. P., Varese, G. C., Casieri, L., Voyron, S., Bertolotto, A., \& Filipello Marchisio, V. (2010). Use of Rhizopus stolonifer (Ehrenberg) Vuillemin in methods for treating industrial wastewaters containing dyes. US Patent No: 7658849.

140. Prigione, V. P., Varese, G. C., Casieri, L., Voyron, S., Bertolotto, A., \& Filipello Marchisio, V. (2010). Use of Cunninghamella elegans lendner in methods for treating industrial wastewaters containing dyes. US Patent No: 7790031.

141. Prigione, V. P., Varese, G. C., Casieri, L., Voyron, S., Bertolotto, A., \& Filipello Marchisio, V. (2011). Use of Rhizomucor pusillus (lindt) schipper in methods for treating industrial wastewaters containing dyes. US Patent No: 7935257.

142. Li, D., He, X., Tao, Y., \& Wang, X. (2011). Pseudomonas alcaliphila MBR and its application in bioreduction and biosorption. US Patent No: 20110269169.

143. Tsezos, M. (1999). Process Metallurgy, 9, 171-173.

144. Tsezos, M., Hatzikioseyian, A., \& Remoudaki, E. (2012). Biofilm reactors in mining and metallurgical effluent treatment: biosorption, bioprecipitation, bioreduction processes. Available from: http:// www.metal.ntua.gr/uploads. Accessed 2 Dec 2012.

145. Jeffers, T. H., Bennett, P. G., \& Corwin, R. R. (1993). Biosorption of metal contaminants using immobilised biomass - field studies. US Bureau of Mines, Report of investigations 9461. 
146. Brierley, J. A., Brierley, C. L., \& Goyak, G. M. (1986). AMT-BIOCLAIM: A new wastewater treatment and metal recovery technology. In R. W. Lawrence, R. M. R. Branion, \& H. G. Ebner (Eds.), Fundamental and applied biohydrometallurgy (pp. 291-308). Amsterdam: Elsevier.

147. Brierley, J. A. (1990). Production and application of a Bacillus-based product for use in metals biosorption. In B. Volesky (Ed.), Biosorption of heavy metals (pp. 305-311). Boca Raton: CRC Press.

148. Eccles, H. (1995). International Biodeterioration \& Biodegradation, 35, 5-16.

149. Barkley, N. P. (1991). Journal of the Air \& Waste Management Association, 41, 1387-1393.

150. Available from: www.bvsorbex.net/sxProcess.pdf (Accessed 1 Sept 2012)

151. Atkinson, B. W., Bux, F., \& Kasan, H. C. (1998). Water SA, 24, 129-135.

152. Chojnacka, K. (2010). Environment International, 36, 299-307.

153. Artola, A., Martin, M. J., Balaguer, M., \& Rigola, M. (2001). Journal of Chemical Technology and Biotechnology, 76, 1141-1146.

154. Tigini, V., Prigione, V., Anastasi, A., Spina, F., \& Varese, G. C. (2011). Scale up of biosorption process for the treatment of the textile wastewaters with fungal biomasses. 7th International Conference on Polymer and Textile Biotechnology, Italy.

155. Zouboulis, A. I., Lazaridis, N. K., \& Matis, K. A. (2002). Journal of Chemical Technology and Biotechnology, 77, 958-964. 